\title{
Weathering Processes in the Ganges-Brahmaputra basin and the riverine alkalinity budget
}

\author{
Albert Galy and Christian France-Lanord \\ Centre de Recherches Petrographiques ét Geochimiques - CNRS, BP 20,54501 \\ Vandceuvre-les-Nancy, France \\ Corresponding author agaly@crpg.cnrs-nancy.fr
}

Galy A. and France-Lanord C. (1999) Weathering processes in the Ganges-

Brahmaputra basin and the riverine alkalinity budget. Chemical Geology 159, 31-60.

doi: 10.1016/s0009-2541(99)00033-9 


\section{Abstract}

We present river chemistry data for a network of rivers draining the western and central Nepal Himalaya. Our sampling locations cover the system from the sources of rivers in Tibet to the Gangetic plain. Water samples were collected throughout the year, including the monsoon season, for rivers in Nepal and for the Ganges and Brahmaputra in Bangladesh.

Rivers draining the North Himalaya are characterized by low discharge under a cold and arid climate. Main stream waters have $\delta^{13} \mathrm{C}_{\text {DIC }}$ near $0 \%$ and high $\left[\mathrm{SO}_{4}{ }^{2-}\right.$ ]$/\left(\left[\mathrm{SO}_{4}{ }^{2-}\right]+\left[\mathrm{HCO}_{3}^{-}\right]\right)$ratios $\left(\mathrm{X}_{\mathrm{SO}_{4}}\right)$ with values around $40 \mathrm{Eq} \%$ and high $\left[\mathrm{Cl}^{-}\right]$. Ca is the dominant cation $\left(\mathrm{Ca}^{2+} / \sum\right.$ cations $=55$ to $75 \mathrm{Eq} \%$, after correction of sodium by chloride). Dissolved sulfate is produced in waters from the TSS whereas chlorine is related to thermal waters. Dissolved sulfate is primarily derived from sulfide oxidation rather than evaporite dissolution. $\delta^{13} \mathrm{C}_{\text {DIC }}$ values of up to $3.9 \%$ show that metamorphic $\mathrm{CO}_{2}$ is an important weathering agent. Rivers of the North Himalayan basins have about $50 \%$ of their alkalinity derived from carbonate dissolution, $20 \%$ from biogenic activity and $30 \%$ from metamorphic $\mathrm{CO}_{2}$.

On the south flank of the Himalaya, rivers are more depleted in ${ }^{13} \mathrm{C}$ and have, on average, lower $\mathrm{X}_{\mathrm{SO}_{4}}$. Most rivers have $\delta^{13} \mathrm{C}_{\mathrm{DIC}}$ and $\mathrm{X}_{\mathrm{SO}_{4}}$ values compatible with a simple mixing between soil $\mathrm{CO}_{2}$ and sulfate derived from sulfide oxidation. During the monsoon, discharge increases by a factor 20 but the total dissolved concentration is only slightly reduced. $\mathrm{X}_{\mathrm{SO}_{4}}$ and $\delta^{13} \mathrm{C}$ decrease while $\mathrm{Ca} / 2$ cations increases, implying enhanced dissolution of pedogenic calcite.

As a whole, the G-B riverine flux of alkalinity derived from silicate weathering is around $2.7 \times 10^{11} \mathrm{~mol} / \mathrm{yr}$, modest at the global scale. Sulphuric acid controls $20-30 \%$ of the weathering reaction in the Brahmaputra and 6 to $9 \%$ in the Ganges. $\mathrm{Na}^{+}$and $\mathrm{K}^{+}$ balance 60 to $65 \%$ of the silicate-derived alkalinity flux, and the long term $\mathrm{CO}_{2}$ consumption by Ganges and Brahmaputra is near $6.4 \times 10^{10} \mathrm{~mol} / \mathrm{yr}$. The flux of metamorphic $\mathrm{CO}_{2}$ converted to alkalinity via weathering reactions is ca. $1 \times 10^{10}$ $\mathrm{mol} / \mathrm{yr}$.

\section{Keywords}

Weathering, Himalaya, Alkalinity, Sulfide, Atmospheric $\mathrm{CO}_{2}$, Metamorphic $\mathrm{CO}_{2}$. 


\section{Introduction}

Dissolved fluxes derived from Himalayan erosion and transported to the ocean by the Ganges and Brahmaputra (G-B) rivers exert a strong influence on the chemical budget of some elements at the global scale (Richter et al., 1992; Krishnaswami et al., 1992; Palmer and Edmond, 1992; Derry and France-Lanord, 1996). Several studies have discussed the effect of silicate weathering of the Himalaya on the global uptake of atmospheric $\mathrm{CO}_{2}$ since the Miocene (e.g. Raymo and Ruddiman, 1992; Goddéris and François, 1996; France-Lanord and Derry, 1997). While there is no doubt that the G-B has a significant impact on the $\mathrm{Sr}$ isotope budget of the ocean, the relationship between $\mathrm{Sr}$ isotopic fluxes and silicate weathering remains debated (e.g. Quade et al., 1997; Mc Cauley, and De Paolo 1997; Singh et al., 1998). The evaluation of these processes, particularly of the $\mathrm{CO}_{2}$ uptake by silicate weathering, requires the characterization of the dissolved load of the G-B with regard to its origin (carbonate, silicate or evaporite) and the type of weathering agent involved. Pioneer studies on the G-B chemistry have shown the predominance of carbonate dissolution over silicate weathering and a relative variability of the riverine chemistry from the Himalayan headwaters down to the flood plain (Handa, 1972; Sarin and Krishnaswami 1984; Sarin et al. 1989). From available data on Himalayan rivers, some typical features can be underlined from north to south (Sarin et al., 1989; Sarin et al., 1992; France-Lanord et al. 1995). Headwaters are characterized by high total dissolved solids (TDS) around $350 \mathrm{mg} / \mathrm{l}$, with high ratios of $\mathrm{SO}_{4}{ }^{2-/} /$ anion . Rivers originating on the southern flank of the Himalaya deliver variable fluxes of dissolved elements, depending on the lithology of their basin. In the flood plain, silicate weathering reactions and tributaries from the south (India) play an important role. Despite these detailed studies, uncertainties remain on the budget of both anions and cations in the G-B, and thus on the budget of silicate alkalinity. In the G-B, 10 to $15 \%$ of the anion charge is sulfate that can be derived from either evaporite dissolution or sulfide oxidation. It is necessary to determine if sulfide oxidation is a significant weathering agent in this system or if the high sulfate values represent only "passive" dissolution of evaporitic units. The chemical difference between eroded sediments and their Himalayan source rocks suggests that silicate alkalinity is primarily in the form of alkali cations, which have a significantly smaller impact on net $\mathrm{CO}_{2}$ consumption than $\mathrm{Ca}-\mathrm{Mg}$ cations (France-Lanord and Derry, 1997). In order to quantify $\mathrm{CO}_{2}$ consumption by weathering of the Himalaya, the sources of sulfate and of base cations must be quantified.

In this study, we characterize the weathering reactions in the different zones of the G-B basin and the origin of the dissolved load in order to refine the budget of silicate weathering in the Himalayan system. The study is based on the chemical analyses of 
stream waters in different locations of the Narayani basin in Nepal Himalaya, and of the G-B in Bangladesh. Special attention has been paid to the seasonal variability of the riverine chemistry, since most of the dissolved flux is delivered during the monsoon. The data base, including major cations and anions and the isotopic composition of dissolved inorganic carbon, helps to constrain the source of carbonic acid involved in the weathering reactions. In addition, the chemistry of precipitation, the geology of the basin, the mineralogy of the bedload and hydrological data are used to refine this budget of Himalayan chemical erosion.

\section{Hydrology and Geology of the Ganges-Brahmaputra basin}

The Ganges-Brahmaputra (G-B) basin drains a surface of ca. $1.66 \times 10^{6} \mathrm{~km}^{2}$ in India, Tibet, Nepal, Buthan and Bangladesh (Fig. 1). Four domains can be defined: the G-B plain, the hills and plateau of India to the south of the G-B plain, the Himalaya, and the southern part of the Tibetan plateau. The discharges of the Ganges and Brahmaputra are 459 and $612 \times 10^{8} \mathrm{~m}^{3} / \mathrm{yr}$, respectively (GRDC, 1994). A sharp climatic contrast exists between Tibet and the rest of the basin. The southern flank of the range and the plain are exposed to monsoonal precipitation ( 1 to $4 \mathrm{~m} / \mathrm{yr}$ ) whereas, to the north of the high range, the Tibetan climate is cold and arid with precipitation around $0.2-0.5 \mathrm{~m} / \mathrm{yr}$. While the respective area proportions for the G-B plain, southern hills, Himalaya and Tibet are 46:20:18:16, the proportions of annual discharge are 32:9:52:7. This reflects the heterogeneous distribution of precipitation over the basin and the dominant role of the Himalaya in collecting precipitation by orographic effect. Following the major geographical limits, the geology of the Himalaya can be divided into four units separated by major thrust systems. The terranes of the southern part of the Tibetan plateau mostly belong to the Tethian Sedimentary Series (TSS), composed primarily of PalaeozoicMesozoic carbonate and clastic sediments (North Indian shelf sediments). Underlying the TSS, the High Himalaya Crystalline (HHC) is the principal formation of the high range. It consists of ortho- and paragneisses, migmatites and highly metamorphosed marbles (Gansser, 1964; Colchen et al., 1986; Le Fort, 1989). The Lesser Himalaya (LH) is composed of variably metamorphosed Precambrian sediments. The lithologies are quartzo-pelitic schists, quartzites, and dolomitic carbonates. The southernmost part of the range consists of the recently uplifted Siwaliks, formed of Mio-Pliocene detrital sediments accumulated in the former Gangetic plain.

\section{Sampling and analyses}


Water samples were collected in the Narayani watershed, which is one of the four main rivers draining Nepal (Fig. 1 \& 2). Sampling includes (1) main tributaries of the Nayarani in the Lesser Himalaya (Kali Gandaki, Marsyandi, Bhuri Gandaki and Trisuli), (2) detailed sampling of the Kali Gandaki from the northern headwaters in the Mustang graben to the south, and (3) minor tributaries of various locations within the basin. Additional basins have been sampled in western Nepal (Karnali, Bheri and Rapti rivers), in Sikkim (Tista river), and some draining the Siwaliks. Samples were collected between May 1993 and April 1997 (Tables 1 to 5), mainly during the dry season, except for the Trisuli and the Bheri rivers which have been sampled repeatedly over one year. The Ganges and Brahmaputra were sampled at different points in Bangladesh during the 1996 monsoon and in winter of 1997 (Fig 1 and Table 5). In Bangladesh we also collected water from the Tista which flows directly from the Himalaya and the Upper Meghna which flows from the Shillong plateau.

All samples were collected from the river bank, filtered through $0.2 \mu \mathrm{m}$ or $0.1 \mu \mathrm{m}$ nylon Millipore filters and stored in 2 bottles free of air. One bottle of water was acidified by adding one drop of strong distilled $\mathrm{HNO}_{3}$. When reported, $\mathrm{pH}$ values were determined in the field. Alkalinity was measured by $\mathrm{HCl}$ titration in the field for some samples and was always within $7 \%$ of the $\mathrm{HCO}_{3}{ }^{-}$determined by charge balance.

The $\delta^{13} \mathrm{C}$ of dissolved inorganic carbon $\left(\delta^{13} \mathrm{C}_{\mathrm{DIC}}\right)$ were measured on $\mathrm{CO}_{2}$ released by acidification with $>100 \% \mathrm{H}_{3} \mathrm{PO}_{4}$ in vacuum. The sample bottles were opened under an $\mathrm{N}_{2}$ atmosphere in a glove box and aliquots of 15 to $20 \mathrm{ml}$ were transferred into the reaction vessel. The acidification will release carbonate for highly saline water but no precipitate has been observed in bottles for river waters. The $\mathrm{CO}_{2}$ released after acidification was extracted while water was trapped as ice at $-80^{\circ} \mathrm{C}$. Total $\mathrm{CO}_{2}$ released was measured manometricaly and analysed for ${ }^{13} \mathrm{C} /{ }^{12} \mathrm{C}$ ratio using a modified VG 602D isotope ratio mass spectrometer. Overall reproducibility is $\pm 0.2 \%$ for $\delta^{13} \mathrm{C}_{\mathrm{DIC}}$.

Major element concentrations were measured by ion chromatography at the CRPG. Separation of $\mathrm{F}^{-}, \mathrm{Cl}^{-}, \mathrm{NO}_{3}^{-}$and $\mathrm{SO}_{4}{ }^{2-}$ was carried out on a $\mathrm{AS} 12 \mathrm{~A}$ column using non-acidified water. Acidified water was passed through a CS10 column in order to analyse $\mathrm{Na}^{+}, \mathrm{K}^{+}, \mathrm{Mg}^{2+}$ and $\mathrm{Ca}^{2+}$. Each ion was calibrated in a range from 0 to $2 \mathrm{mg} / \mathrm{l}$ and the water samples were diluted to fit this range. The detection limit for $\mathrm{F}^{-}$is $2 \mathrm{ppb}$, for $\mathrm{NO}_{3}$ - is $10 \mathrm{ppb}$ and for all other ions, the measured amounts are well above their detection limits. Reproducibility is around $10 \%$ (relative) for all ions. $\mathrm{HCO}_{3}{ }^{-}$was determined by charge balance from the other ions. Silica was measured by spectrophotometric measurement of the Mo blue complex and 22 samples were duplicated by atomic absorption. These two methods gave comparable results, ruling out the occurrence of significant $\mathrm{Si}$ in colloidal form. 


\section{Results}

The data from the Central Nepal basin are presented in Tables 1,2, and 3 for the Kali Gandaki, Trisuli and other rivers, respectively (Fig. 2). For convenience, the samples have been listed in the tables from north to south. Data from the Western Nepal basins and Siwaliks are listed in table 4. Data from river samples in Bangladesh are given in table 5 .

Chemical compositions of Himalayan rivers are highly variable, with total dissolved solid (TDS) ranging from 6 to $880 \mathrm{mg} / \mathrm{l}$. Both the location in the basin and the lithology of the drainage appears to control their chemical characteristics. These are listed in table 6 following the main geographic divisions. All river waters have high relative $\left[\mathrm{Ca}^{2+}\right]$, with $\mathrm{Ca}^{2+}$ representing more than $50 \%$ eq of the total cation charge $\left(\sum^{+}\right)(\mathrm{Fig}$ 3a). Rivers draining dominantly gneissic terranes in the south flank, some Siwaliks rivers, and basins with a large evaporite component, such as the higher Kali Gandaki, have $\left[\mathrm{Na}^{+}\right]$over $30 \%$ eq of the total cation charge. Overall, rivers draining North flank basins have the highest concentration and are characterized by high relative $\left[\mathrm{SO}_{4}{ }^{2-}\right]$ and locally high $\left[\mathrm{Cl}^{-}\right]$(Fig 3b). $\mathrm{pH}$ values are always high, between 7.5 and 9.3. With the exception of rivers from gneissic drainage, river waters are always saturated with respect to calcite. This is consistent with the fact that rivers carry 5 to $40 \%$ detrital carbonates in the bedload and suspended load. Dissolved inorganic carbon (DIC) has $\delta^{13} \mathrm{C}_{\text {DIC }}$ ranging between ca. $0 \%$ in the north to $-12 \%$ in Bangladesh. For most samples, $\mathrm{pCO}_{2}$ concentrations are 5 to $25 \%$ higher than calculated or measured $\left[\mathrm{HCO}_{3}^{-}\right]$, implying that waters are significantly supersaturated with respect to atmosphere for dissolved $\mathrm{CO}_{2}$. The supersaturation reflects equilibration of these waters in a high $\mathrm{pCO}_{2}$ environment, such as soils or ground water.

The Kali Gandaki has its source in Tibet and descends to the Gangetic plain (Fig. 4). All major Himalayan rivers follow a similar profile (Seeber and Gornitz, 1983), but unlike other major rivers, the upper part of the Kali Gandaki lies in the Mustang graben (one of the Tibetan Neogene grabens). The north basin is characterized by low precipitation ( 25 to $50 \mathrm{~cm} / \mathrm{yr}$ ), high TDS, and the highest values of $\mathrm{Cl}^{-}$and $\mathrm{SO}_{4}{ }^{2-}$ in the whole river system. $\left[\mathrm{Cl}^{-}\right]$and $\left[\mathrm{SO}_{4}{ }^{2-}\right]$ are however independent as water from the TSS never have high $\left[\mathrm{Cl}^{-}\right](<20 \mu \mathrm{mol} / \mathrm{l})$. It is only in the graben filling conglomerate that waters have high $\left[\mathrm{Cl}^{-}\right]$. Dissolved inorganic carbon is characterized by extremely high $\delta^{13} \mathrm{C}$ around $0 \%$ in the main stream of the Kali Gandaki and up to $+3.9 \%$ for some tributaries. Cations are dominated by $\mathrm{Ca}^{2+}$, which remains the dominant cation all along the river course. When crossing the high range, precipitation increases very rapidly to reach $\approx 2 \mathrm{~m} / \mathrm{yr}$. Despite this increased runoff, TDS remain high, indicating an increase of 
the chemical denudation rate on the southern slope of the range. $\delta^{13} C_{\text {DIC }}$ decreases gradually as a response to the contribution of the south flank tributaries which have $\delta^{13} \mathrm{C}_{\mathrm{DIC}}$ around $-8 \%$. In the south, the Kali Gandaki is characterized by high relative $\mathrm{Cl}^{-}$ and $\mathrm{SO}_{4}{ }^{2-}$ contents, if compared to most other rivers. These characteristics clearly reflect the contribution of the headwaters in Mustang.

\section{Discussion}

\subsection{Atmospheric input and anthropogenic effects.}

The rain water contribution has been estimated from our new and published analyses of rain waters listed in table 7 . While the chemistry of rainwater is highly variable, the elemental ratios imply that its chemistry is derived from sea water aerosols as well as from dissolution of continental dust. Excess $\mathrm{Ca}^{2+}$ and $\mathrm{Mg}^{2+}$ are related to input of terrestrial carbonate and sulfate dust which dissolve in rain water (Sequeira and Kelkar, 1978; Wake et al., 1993). The Cl/Na ratio is lower than that of sea water as well as of oceanic aerosols (Tsunogai et al., 1972) and implies a terrestrial silicate dust contribution for $\mathrm{Na}$ as well. Atmospheric inputs are more important close to the Ganges delta than in Himalaya. The $\mathrm{Ca} / \mathrm{Na}$ and $\mathrm{Mg} / \mathrm{Na}$ ratios are lower in the plain than in the mountain implying an increase of the dust contribution away from the sea.

Estimates of cyclic salt contribution also imply that evapotranspiration is taken into account. In Nepal, both direct measurement (Alford, 1992) and calculated potential evapotranspiration imply that ca. $25 \%$ of the precipitation is affected. In the Ganges plain, evapotranspiration is more important and likely reaches $50 \%$ of the precipitation (e.g. Krishnamurthy and Bhattacharya, 1991). On this basis, we estimate the rain water contribution to the riverine dissolved load from the average rain water concentrations multiplied by 1.33 for $25 \%$ evapotranspiration in the Himalaya and 2 for $50 \%$ evapotranspiration in the Gangetic plain. For rivers in Bangladesh we used a composite of $50 \%$ Himalaya rainwater and $50 \%$ plain rainwater. The proportion of atmospheric input is about 1 to $10 \%$ of the TDS, except for some high altitude small catchments in the $\mathrm{HHC}$ where it can reach $65 \%$.

Anthropogenic activity can modify the chemical signature of river water. In Nepal, Collins and Jenkins (1996) have shown that catchments in agricultural zones are enriched in nitrate and sulfate by 5 to $10 \mu \mathrm{mol} / \mathrm{l}$ over similar forested catchments. This is likely due to the use of $\mathrm{N}$ - and $\mathrm{K}$-fertilizers. Some of high altitude rivers (Mailung, Tadi, Hundi), or those with little forested watersheds (Mustang area along the Kali Gandaki 
and the Bheri at Dunai) have significant concentrations of nitrate which may reflect the influence of livestock. For all other rivers this contribution remains minor.

\subsection{Weathering processes :}

\subsubsection{Acid involved}

One of the unknown in the alteration process is the source of the acid involved in the reaction. Weathering reactions can involve acids from the following sources:

(1) Atmospheric $\mathrm{CO}_{2}$ dissolved in surface water. In carbonate catchments, it has been shown that kinetic limitations occur during dissolution of carbonate by atmospheric $\mathrm{CO}_{2}$ leading to maximum $\left[\mathrm{HCO}_{3}^{-}\right]$around $150-200 \mu \mathrm{mol} / \mathrm{l}$ (Fairchild et al, 1994). This reaction will provide $\delta^{13} \mathrm{C}_{\text {DIC }}$ around -2 to $+2 \%$.

(2) Soil $\mathrm{CO}_{2}$. Biologic activity in soil enhances $\mathrm{pCO}_{2}$ far above the atmospheric levels. $\mathrm{HCO}_{3}$ - in equilibrium with $\mathrm{CO}_{2}$ produced by degradation of $\mathrm{C} 3$ plant should have a $\delta^{13} \mathrm{C}$ around $-18 \%$. A silicate weathering reaction consuming soil $\mathrm{CO}_{2}$ should then produce $\mathrm{HCO}_{3}{ }^{-}$at $-18 \%$, whereas carbonate dissolution should release $\mathrm{HCO}_{3}{ }^{-}$at $-9 \%$, because half of the $\mathrm{HCO}_{3}$ - is derived from the carbonate.

(3) Metamorphic $\mathrm{CO}_{2}$. We sampled thermal springs highly enriched in ${ }^{13} \mathrm{C}$ at five locations in the Mustang graben at the contact between the graben-filling conglomerate and the basement formations. These springs are always characterized by $\delta^{13} \mathrm{C}$ above $+10 \%$, $\left[\mathrm{HCO}_{3}{ }^{-}\right]$between 6000 and $120000 \mu \mathrm{mol} / \mathrm{l}$, variable [Cl-] and $\left[\mathrm{SO}_{4}{ }^{2-}\right]$, and are associated with $\mathrm{CO}_{2}$ degassing. The production of dry $\mathrm{CO}_{2}$ at depth by metamorphic decarbonatation around $300-400^{\circ} \mathrm{C}$ creates gas enriched in ${ }^{13} \mathrm{C}$ by 2 to $6 \%$ with regard to the original rock (Shieh and Taylor, 1969; Friedman and O'Neil, 1977). The evolved $\mathrm{CO}_{2}$ is further dissolved in ground water that produces $\mathrm{HCO}_{3}$ - having a $\delta^{13} \mathrm{C} 6-10 \%$ higher than that of the gas (Mook et al., 1974). A contribution of this type of alkalinity is clear in the Narsing river with $\delta^{13} \mathrm{C}=+3.9 \%$ requiring a source of enriched $\mathrm{CO}_{2}$. One spring water which flows into this river has been analysed with $\left[\mathrm{HCO}_{3}^{-}\right]$around 30000 $\mu \mathrm{mol} / \mathrm{l}$ and $\delta^{13} \mathrm{C}_{\mathrm{DIC}}=+13.5 \%$.

(4) Sulfuric acid derived from sulfide oxidation. Sulfuric acid will react with calcite and silicate. The $\mathrm{HCO}_{3}{ }^{-}$released by this reaction have the $\delta^{13} \mathrm{C}$ around zero permil.

The characteristic and contribution of acids to the weathering budget can be estimated using $\delta^{13} \mathrm{C}_{\mathrm{DIC}}$, which varies with the source of the carbonic acid, and the sulfate proportion $\left(\mathrm{XSO}_{4} \mathrm{eq} \%\right)$. The proportion of carbonate/silicate altered and of the four 
weathering acids provide the covariations of $\mathrm{X}_{\mathrm{SO}_{4}}$ with $\delta^{13} \mathrm{C}_{\mathrm{DIC}}$ shown in figure 5 . The alkalinity budget and $\mathrm{X}_{\mathrm{SO}_{4}}$ can be described by the 3 equations:

$\left[\mathrm{HCO}_{3}^{-}\right]_{\text {tot }}=\left[\mathrm{HCO}_{3}^{-}\right]_{\text {carb }}+\left[\mathrm{HCO}_{3}^{-}\right]_{\text {bio }}+\left[\mathrm{HCO}_{3}^{-}\right]_{\text {meta }}+\left[\mathrm{HCO}_{3}^{-}\right]_{\text {atm }}$ $\delta^{13} \mathrm{C}_{\text {tot }}=\left(\sum_{i}\left[\mathrm{HCO}_{3}^{-}\right]_{i} \times \delta^{13} \mathrm{C}_{i}\right) /\left[\mathrm{HCO}_{3}{ }^{-}\right]_{\text {tot }}$ $\mathrm{X}_{\mathrm{SO}_{4}}=\left(\left[\mathrm{SO}_{4}{ }^{2-}\right]_{\text {sulfide }}+\left[\mathrm{SO}_{4}{ }^{2-}\right]_{\text {evaporite }}\right) /\left(\left[\mathrm{SO}_{4}{ }^{2-}\right]_{\text {tot }}+\left[\mathrm{HCO}_{3}{ }^{-}\right]_{\text {tot }}\right)$ where total alkalinity is the sum of $\mathrm{HCO}_{3}$ - derived from $i$ inputs: carbonate dissolution (carb), biologic (bio), metamorphic (meta) and atmospheric (atm). This system can be simplified assuming that : (1) direct weathering by atmospheric $\mathrm{CO}_{2}$ is negligible, (2) sulfuric and carbonic acids alter carbonate and silicate without any selectivity, (3) $\left[\mathrm{HCO}_{3}{ }^{-}\right.$ ]$_{\text {carb }}=\left[\mathrm{Ca}^{2+}\right]-\left[\mathrm{Na}^{+*}\right] \times 0.2$ (see appendix). In the case of weathering without metamorphic $\mathrm{CO}_{2}$, compositions plot on the curves drown on figure 5 for different proportion of carbonate to silicate altered. For the end member case where all weathering is produced by reaction with $\mathrm{H}_{2} \mathrm{SO}_{4}, \mathrm{X}_{\mathrm{SO}_{4}}$ vary between 0.5 for dissolution of carbonate and 1 for silicate (Fig. 5).

\subsubsection{Mustang basin - Kali Gandaki headwaters}

Main stream Kali Gandaki waters are characterized by high $\delta^{13} \mathrm{C}_{\mathrm{DIC}}$ (close to $0 \%$ ), high sulfate content around $40 \mathrm{eq} \%$, high chlorine content around $10 \mathrm{eq} \%$, and dominant proportion of $\mathrm{Ca}$ in the cations $\left(\mathrm{X}_{\mathrm{Ca}}=\mathrm{Ca}^{2+} / \sum\right.$ cations of 55 to $75 \mathrm{eq} \%$, after correction of sodium by chloride). Waters are always over saturated with respect to calcite, and detrital carbonate was found in all bedload sands. High $\left[\mathrm{Cl}^{-}\right]$are restricted to catchment draining the conglomerate formations which fill the Mustang graben. Surrounding tributaries draining the TSS formations have low $\left[\mathrm{Cl}^{-}\right]$. Therefore, $\mathrm{Cl}^{-}$is likely derived from thermal spring circulations enriched in $\mathrm{Cl}^{-}$and/or from the leaching of salted lenses described in the basal formation of the conglomerate (Tshering and Bhandari, 1973 in Fort, 1996).

Except in the extreme north, Mustang river waters have high sulfate contents. Sulfate can be derived from either dissolution of $\mathrm{CaSO}_{4}$ minerals in sedimentary evaporites or from oxidation of sulfide minerals. Both source are possible in the Mustang context since (1) high $\left[\mathrm{Cl}^{-}\right]$imply that evaporitic material is altered and (2) pyrite is present in the Mesozoic formations of the TSS (Bordet et al 1971). Saline waters in glacial environments are frequently associated to this last reaction (Vennum, 1980; Chillrud et al., 1994; Fairchild et al, 1994; Williams et al., 1995). The evaporitic origin is not supported by the lack of correlation between $\left[\mathrm{Cl}^{-}\right]$and $\left[\mathrm{SO}_{4}{ }^{2-}\right]$. Sulfate is released in the TSS waters whereas chloride concentrations remain low. The most extreme example is NAG24 (table 3) which is glacial water flowing on TSS terrain and contains 
only $4 \mu \mathrm{mol} / / \mathrm{Cl}-$ for $2852 \mu \mathrm{mol} / / \mathrm{l}$ of $\mathrm{SO}_{4}{ }^{2-}$. For these reasons we argue that the dissolved sulfate mostly derives from sulfide oxidation.

$\delta^{13} \mathrm{C}_{\text {DIC }}$ are high in almost all Mustang waters which is not common in rivers (e.g. review in Mook and Tan, 1991). $\delta^{13} \mathrm{C} \approx 0 \%$ could be reached via several scenarios. $\mathrm{CO}_{2}$ equilibration with the atmosphere is unlikely because these rivers are significantly supersaturated in $\mathrm{CO}_{2}$ with respect to atmosphere. Degassing of $\mathrm{CO}_{2}$ tends to increase the $\delta^{13} \mathrm{C}$ of remaining DIC, but such degassing will only increase the $\delta^{13} \mathrm{C}_{\text {DIC }}$ by about $0.5 \%$. Photosynthetic activity tends to increase $\delta^{13} \mathrm{C}_{\text {DIC }}$ (Pawellec and Veizer, 1995) but is not important in the cold and arid climate of this basin. Carbonate dissolution promoted by dissolved atmospheric $\mathrm{CO}_{2}$ will deliver DIC around $0 \%$ but these reactions cannot account for the high $\mathrm{CO}_{2}$ concentrations measured in these waters. Finally, the weathering of carbonate by sulfuric acid delivers DIC around $0 \%$. Given the $\mathrm{X}_{\mathrm{Ca}}$ of these rivers, the $\mathrm{X}_{\mathrm{SO}_{4}}$ ratio should be between 0.65 and 0.80 if sulfuric acid was the only weathering agent or even higher if some $\mathrm{SO}_{4}{ }^{2-}$ is derived from evaporite. Our data are lower around 0.5 and imply that carbonic acid also contributes to weathering reactions (Fig. 6a). In figure 6a, all samples lie to the right of the mixing trend between the $\mathrm{H}_{2} \mathrm{SO}_{4}$ and the "Biological" $\mathrm{CO}_{2}$. A contribution of metamorphic $\mathrm{CO}_{2}$ could satisfy the carbon isotopic budget. To the extreme north, [ $\left.\mathrm{SO}_{4}{ }^{2-}\right]$ are low and samples of the main stream of the Kali Gandaki (LO 49) have variable $\delta^{13} \mathrm{C}_{\text {DIC }}\left(-3.2\right.$ and $+1.3 \%$ ) and $\left[\mathrm{Cl}^{-}\right]$(270 and $930 \mu \mathrm{mol} / \mathrm{l})$. One minor local tributary (LO 25 ) has lower $\delta^{13} \mathrm{C}_{\mathrm{DIC}}$ at $-6.7 \%$ and low $\left[\mathrm{Cl}^{-}\right.$ ], reflecting a greater influence of soil weathering reactions. On the other hand, nearby spring waters have very high $\left[\mathrm{Cl}^{-}\right](93000 \mu \mathrm{mol} / \mathrm{l})$ and $\delta^{13} \mathrm{C}_{\mathrm{DIC}}$ around $+10 \%$, with $\left[\mathrm{HCO}_{3}{ }^{-}\right]$of $36800 \mu \mathrm{mol} / \mathrm{l}$. The two samples of the Kali Gandaki are consistent with mixing between spring waters enriched in metamorphic $\mathrm{CO}_{2}$ and surface water enriched in biologically derived $\mathrm{CO}_{2}$ (represented by sample LO 25). Downstream, the chemistry of the Kali Gandaki becomes strongly enriched in sulfate while its $\delta^{13} \mathrm{C}_{\text {DIC }}$ varies little between -1.4 and $0.4 \%$ (Fig. 6a). These chemical signatures indicate the contribution of a tributary where sulfide oxidation and metamorphic $\mathrm{CO}_{2}$ are important weathering agents, such as in sample LO 96.

Following the simplifications of the alkalinity budget (section 5.2), we find that about $50 \%$ of the alkalinity is derived from carbonate dissolution, $20 \%$ from biogenic $\mathrm{CO}_{2}$, and $30 \%$ from metamorphic $\mathrm{CO}_{2}$. This rough budget underlines the importance of metamorphic $\mathrm{CO}_{2}$ in the chemical budget of these rivers.

The Kali Gandaki headwaters are characterized by the role of sulfide oxidation and metamorphic $\mathrm{CO}_{2}$ as weathering agents. The importance of sulfuric acid could be a relatively general feature of the north flank basins because most rivers flowing from the north Himalaya have high [ $\left.\mathrm{SO}_{4}{ }^{2-}\right]$. In Nepal, the Bhote Kosi, Marsyandi, Seti, and 
Bheri in their upper reaches have high $\left[\mathrm{SO}_{4}{ }^{2-}\right]$. In the Garhwal Himalaya, high [ $\left.\mathrm{SO}_{4}{ }^{2-}\right]$ in river water or in melt waters were also proposed to partially result from oxidation of pyrite (Sarin et al., 1992; Hasnain and Thayyen, 1996). We have no data which permit us to evaluate the importance of metamorphic $\mathrm{CO}_{2}$ as a weathering agent in these north Himalayan basins. The metamorphic $\mathrm{CO}_{2}$ is restricted to the graben of the Thakkhola in the Kali Gandaki, but this type of heavy dissolved carbon was also suggested for the Tibetan lakes (Fontes et al., 1996) and may represent a general feature for catchment linked to major tectonic depression.

\subsubsection{South flank rivers}

When crossing the high Himalaya, large rivers like the Kali Gandaki have decreasing $\delta^{13} \mathrm{C}_{\text {DIC }}$ (Fig. 4). This is due to progressive contribution of south flank catchments, where two types of rivers can be defined on the basis of the lithology of their basin . Rivers flowing in carbonate-free basin have low TDS, around 15 to $50 \mathrm{mg} / \mathrm{l}$, and lower $\mathrm{X}_{\mathrm{Ca}}$. In these rivers the cyclic contribution is important and may represents up to $50 \%$ of the dissolved load. For this reason, we will use data corrected for cyclic contribution (marked by an asterisk) in the following discussion. Basin with carbonate units from the TSS, HHC or LH have higher TDS (100 to $270 \mathrm{mg} / \mathrm{l}$ ) linked to a higher $\mathrm{X}_{\mathrm{Ca}}$. In both river types, the $\mathrm{X}_{\mathrm{SO}_{4}}$ ratio is variable, between 0.05 and 0.35 , even after correction for cyclic sulfate. Altogether, these rivers have lower $\delta^{13} \mathrm{C}_{\text {DIC }}$ than the north flank rivers, implying that biologically derived alkalinity becomes more important. This is consistent with the higher proportion of forested area on the south flank of the Himalaya. The $\delta^{13} \mathrm{C}_{\mathrm{DIC}}$ varies from -12 to $-3 \%$ and tends to increase with sulfate in the dissolved load. In the $\delta^{13} \mathrm{C}_{\mathrm{DIC}}-\mathrm{X}_{\mathrm{SO}_{4}}$ space, most samples are compatible with a model of alteration driven by both $\mathrm{H}_{2} \mathrm{SO}_{4}$ and biologically derived $\mathrm{HCO}_{3}{ }^{-}$. No anhydrite or gypsum has been described in the $\mathrm{HHC}$ or $\mathrm{LH}$, whereas sulfides are present in all these formations. In the south flank catchments of Kumaun Himalaya (Bartarya, 1993), some formations of the LH contain pyrite that was suggested to be the source of sulfate (around $300 \mu \mathrm{mol} / \mathrm{l})$ in river water, while $\left[\mathrm{Cl}^{-}\right]$remained low $(65 \mu \mathrm{mol} / \mathrm{l})$. Hence, as for the north Himalayan basins, sulfide dissolution appears to be the most likely source of dissolved sulfate in river water.

The alkalinity budget is certainly more complex than a simple mixing between biologically derived $\mathrm{HCO}_{3}{ }^{-}$and $\mathrm{H}_{2} \mathrm{SO}_{4}$. The $\delta^{13} \mathrm{C}$ of the biological $\mathrm{HCO}_{3}{ }^{-}$, chosen at $18 \%$, is likely to be different for the high altitude samples where soils are poorly developed and for the LH samples where thick soils are developed under dense mixed jungle. However, some high altitude stream samples have low $\delta^{13} \mathrm{C}_{\mathrm{DIC}}(-9.5$ to $-8.5 \%$ ). 
This shows that, even where soil is poorly developed, the biological activity enhances $\mathrm{pCO}_{2}$ and thus weathering reactions. Second, the $\delta^{13} \mathrm{C}$ of carbonate rocks is variable from $+1 \%$ in the TSS to $-2 \%$ in the LH (Galy et al., submit). In addition, metamorphic $\mathrm{CO}_{2}$ may contribute to the alkalinity. This is likely the case for $\mathrm{NH} 39$ that has been sampled near the MCT, very close to the hot springs (Tatopani) of the Seti khola. Two samples of these hot springs have a $\delta^{13} \mathrm{C}_{\mathrm{DIC}}$ of +3.7 and $+2.1 \%$. The Langtang khola (LO 257 and NH 100) was also sampled near hot springs in Shyabrubensi which have high $\left[\mathrm{HCO}_{3}^{-}\right]$and $\delta^{13} \mathrm{C}$. However, most hot springs from the south flank have low $\delta^{13} \mathrm{C}_{\mathrm{DIC}}$ and the influence of hot spring waters on south flank rivers is probably only local.

\subsubsection{Main rivers and annual variability}

Main Himalayan rivers sampled in the LH have chemical characteristics inherited from the contribution of the different basins. The range of variation of $\delta^{13} \mathrm{C}_{\mathrm{DIC}}$ and $\mathrm{X}_{\mathrm{SO}_{4}}$ remains very large (-13 to $-4 \%$ and 0.07 to 0.22 , respectively. Fig. 6 b). It is tempting to relate the values observed for the different main rivers to the characteristics of their drainage. For instance, the lower Kali Gandaki samples have all high $\mathrm{X}_{\mathrm{SO}_{4}}$ reflecting the contribution of its upper basin. However, the seasonal variability of the chemical signature at a given location is large and most of our sampling locations have been sampled only once. The sampling of the Trisuli river at Betrawati over one year has a chemical variability which overlaps almost entirely the range of variation of the major Himalayan rivers (Fig. 6b).

The Trisuli river at Betrawati shows systematic trends during and belong the monsoon season (Fig. 7). The onset of the monsoon is marked by a $20 \%$ increase in TDS, despite river discharge increases by a factor 10 . This is the result of an increased input of $\mathrm{HCO}_{3}{ }^{-}$and $\mathrm{Ca}^{2+}$, whereas $\left[\mathrm{SO}_{4}{ }^{2-}\right],\left[\mathrm{Na}^{+}\right],\left[\mathrm{Mg}^{2+}\right]$, and $[\mathrm{Si}]$ decrease over the same period. This trend is reversed after mid July until the end of the monsoon. Afterward, TDS increases together with $\mathrm{X}_{\mathrm{SO}_{4}}$ and $\mathrm{X}_{\mathrm{Na}}$, and $\left[\mathrm{Ca}^{2+}\right]$ concentrations become positively correlated to $\left[\mathrm{Mg}^{2+}\right]$. These variations imply two distinct trends during and outside the monsoon (Fig. 8). During the monsoon, the variation is essentially driven by the input of $\mathrm{Ca}^{2+}$ and $\mathrm{HCO}_{3}{ }^{-}$which reach a maximum around mid July.

Swelling processes imply that ground water in the sub-surface aquifer are flushed out during the early rains. The average chemistry of ground water is difficult to estimate but March-April river chemistry may be a proxy as the proportion of aquifer is high during the dry period. Therefore the hystheresis process at the beginning of the monsoon 
will show and increase of the TDS correlated with the rise the $\mathrm{XSO}_{4}$. This can be the case in May, when the first precipitation reach the range (Climatological records of Nepal). However the chemical evolution of the Trisuli in July (Fig. 7 \& 8) can not be the result of swelling processes.

One possible source of this trend is the input of $\mathrm{CaCO}_{3}$ rich rain water in the system at the beginning of the monsoon. Himalayan rain water can have $\mathrm{Ca}^{2+}$ concentrations as high as 100 to $300 \mu \mathrm{mol} / \mathrm{l}$, probably due to dust input from central Asia (Wake et al., 1990). Precipitation with high $\left[\mathrm{Ca}^{2+}\right]$ could explain the observed trend during the monsoon, however it is likely that precipitation would have a $\delta^{13} \mathrm{C}_{\mathrm{DIC}}$ near $0 \%$, whereas Trisuli river samples during the monsoon show a decrease in $\delta^{13} \mathrm{C}_{\text {DIC }}$ toward a minimum of $-10 \%$. The observed increase in $\left[\mathrm{Ca}^{2+}\right]$ and $\left[\mathrm{HCO}_{3}{ }^{-}\right]$is therefore more likely due to the dissolution of calcite in the basin. Enhanced detrital calcite dissolution is possible in the river since suspended load concentration reach its maximum in July when it is multiplied by 20 with regard to the dry season average. However, detrital calcite dissolution in the river would raise rather than lower $\delta^{13} \mathrm{C}_{\text {DIC }}$. Alternatively it is possible that pedogenic calcite formed in soils during the dry season is preferentially dissolved at the beginning of the monsoon. Pedogenic carbonate derived from the respiration of $\mathrm{C} 3$ plant material has low $\delta^{13} \mathrm{C}$ (Cerling et al., 1989). We do not have data on pedogenic carbonate concentration in soils but the observed trend in the Trisuli water would require dissolution of only $0.01 \mathrm{wt} \%$ of calcite assuming leaching $10 \mathrm{~cm}$ thick soils over the whole basin. This hypothesis appears therefore as the most likely. During the dry season, the chemical signature of the Trisuli is very similar to that of its northern tributary, the Bhote kosi. There is no relationship between $\mathrm{X}_{\mathrm{SO}_{4}}$ and $\delta^{13} \mathrm{C}_{\mathrm{DIC}}$ which is likely due to the fact that during the period of low discharge the influence of hot springs with high $\delta^{13} \mathrm{C}_{\text {DIC }}$ is important.

The trend of calcite dissolution during the monsoon is clearly observed for the Trisuli and the Tista (increasing $\mathrm{Ca}^{2+} / \sum$ cations, $\mathrm{HCO}_{3}-/ \sum$ anions; Table 2 and 5). Other rivers appear to show the same seasonal trend, although less pronounced (Bheri Table 3 and data in Sarin, 1989). The effect of pedogenic carbonate dissolution is more apparent in the Trisuli and the Tista because limestone dissolution does not overprint their chemical signature as strongly as in other basins. The proposed effect of pedogenic carbonate leaching at the beginning of the monsoon may be widespread.

\subsubsection{Ganges and Brahmaputra}

The Ganges and Brahmaputra sampled in Bangladesh during the monsoon (Table 5) have chemical characteristics very similar to those of the main Himalayan rivers at the outflow of the range. They are also close to the mean annual composition reported by the 
GEMS/Water program (UNESCO). During the dry season, the Brahmaputra follows an evolution similar to that of Himalayan rivers, with a slight increase of TDS (105 to 153 $\mathrm{mg} / \mathrm{l}$ ) and an increase of $\mathrm{X}_{\mathrm{SO}_{4}}$ and $\delta^{13} \mathrm{C}_{\text {DIC }}$ (Fig 6b). In contrast, TDS in the Ganges almost triples (125 to $370 \mathrm{mg} / \mathrm{l}$ ) due to the general increase of ion concentrations, with the notable exception of $\mathrm{K}^{+}$and $\mathrm{SO}_{4}{ }^{2-}$. The observed trend is consistent with data reported by Sarin et al. (1989) for the Gangetic plain. These authors have shown that during the dry season, the influence of southern tributaries and of weathering processes in the flood plain become significant relative to Himalayan input. $\delta^{13} \mathrm{C}_{\mathrm{DIC}}$ of the Ganges increases by about $2 \%$ during the dry season, while $\mathrm{X}_{\mathrm{SO}_{4}}$ decreases from 0.10 to 0.03 (Fig 6b). It is possible that this trend reflects a change in the isotopic composition of the biologically derived DIC. The Gangetic plain and the southern tributary catchments are in the C4 photosynthetic zone. consequently, the $\delta^{13} \mathrm{C}_{\text {DIC }}$ in soils should be higher by several \%o than for the Himalayan soils (e.g. Cerling et al., 1989)

\subsection{Silicate to carbonate weathering}

\subsubsection{Chemical budget}

Soluble elements in rivers are a mixture of atmospheric input and weathering of silicate, carbonate, sulfide and evaporite minerals. For any element $\mathrm{X}$ we can therefore write the budget equation:

$[\mathrm{X}]_{\text {river }}=\mathrm{X}_{\text {cyclic }}+\mathrm{X}_{\text {evaporite }}+\mathrm{X}_{\text {carbonate }}+\mathrm{X}_{\text {silicate }}+\mathrm{X}_{\text {sulfide }}+\mathrm{X}_{\text {anthropogenic }}$

The mixing relationships of elemental or isotopic ratios can help to identify and quantify the end members and their relative proportions. In order to decipher the relative contribution of the different end members, we apply a forward modelling of the river chemistry, complemented by constraints of geology and the chemistry of stream sediments. Selected small catchments of given lithology define the chemical characteristics for weathering of different rocks units. This allowed to express the silicate to carbonate budget by the ratio $\mathrm{X}_{\text {sil }}$ and is presented in appendix. The $\mathrm{X}_{\text {sil }}$ is the ratio of dissolved cations from silicates over the sum of dissolved cations from silicates plus carbonates expressed in eq\%.

The main error on this estimate arises from $\mathrm{Mg}_{\text {silicate }}$ and $\mathrm{Ca}_{\text {silicate. We can }}$ consider that $0.15<\left(\mathrm{Ca}^{*} / \mathrm{Na}^{*}\right)_{\text {sil }}<0.25$ and $0.25<\left(\mathrm{Mg}^{*} / \mathrm{K}^{*}\right)_{\text {sil }}<0.75$ (Fig. 9). When applying these ranges of values, the propagated relative uncertainty on $\mathrm{X}_{\text {sil }}$ is less than $22 \%$. This upper limit applies to samples with very low $\mathrm{X}_{\text {sil }}$ values; more typically the uncertainty is $15 \%$. The calculation of $\mathrm{X}_{\text {sil }}$ is only relevant for catchments that are 
large enough to average the chemical heterogeneity of bedrock formations, and have TDS high enough so that cyclic contributions are minor. The silicate to carbonate weathering ratio will therefore be discussed for large basins only.

\subsubsection{Spatial variability of $\mathrm{X}_{\text {Sil }}$.}

If we examine only the major basins, for which the lithology is always mixed, $\mathrm{X}_{\text {sil }}$ shows systematic variability. The catchments of the north flank rivers are carbonaterich and correspond to the lowest $\mathrm{X}_{\text {sil }}(0.07 \pm 0.02$ for the Upper Kali Gandaki). Rivers with large basins in the TSS have low $\mathrm{X}_{\text {sil }}$ : Kali 0.06 to 0.09 ; Marsyandi 0.07 ; Bheri 0.06 to 0.10 . The Trisuli or the Tista, which have a small fraction of their catchment areas in the TSS, have high $X_{\text {sil }}$ around $0.19 \pm 0.03$ and $0.31 \pm 0.07$, respectively.

At the G-B basin scale, the main Himalayan tributaries have variable proportions of carbonate terranes, and $X_{\text {sil }}$ varies from 0.10 to 0.31 . The Ganges and the Brahmaputra have $X_{\text {sil }}=0.18-0.23$ and $0.12-0.17$, respectively. These values could simply imply that the Brahmaputra basin has more carbonate than the Ganges basin does, in contradiction to the geology of the Himalayan parts of their basins. More likely, the values are a reflection of an higher physical/chemical erosion in the Brahmaputra basin. In the Ganges, the apparent enhanced relative rate of silicate weathering may reflect processes in the Siwaliks basins and in the Ganges flood plain. Rivers draining the Siwaliks are characterized by $\mathrm{X}_{\text {Sil }}$ between 0.2 and 0.7 , the highest in the system (Table 4). For the flood plain, data of Sarin et al.(1989) on the Gomti river, which only drains the plains, and for ground waters have a $\mathrm{X}_{\text {sil }}$ around 0.35 , significantly higher than that of the Ganges. We lack yearly records and sufficient hydrological data to quantify the exact influence of both domains, but it is clear that weathering in the lowlands and in the flood plain tends to increase the ratio of silicate weathering in the Ganges. The observation that the flood plain is an important site for silicate weathering is consistent with the long term record of Himalayan weathering preserved in the Bengal Fan (Derry and France-Lanord, 1996).

\subsubsection{Rate of chemical erosion}

Chemical erosion can be estimated from our budget of silicate/carbonate weathering and surface and hydrological data available for the basin. This type of approach allows us to compare rates of erosion between different basin where we have sufficient data to estimate yearly discharge. Therefore we present chemical erosion rates only for the Narayani, Trisuli, Bheri, Tista, and G-B (Table 8). 
The Trisuli and Bheri annual records exhibit a large increase of both carbonate and silicate chemical erosion with the onset of the monsoon. The silicate chemical erosion rates (SCE) are similar in these basins, while the carbonate chemical erosion rates (CCE) are always 3 to 4 times higher in the Bheri watershed. The Bheri basin is rich in carbonate rocks compared, to the Trisuli and Tista, and the difference in the CCE is likely to result primarily from the lithology of the respective catchments. When the lithology is not the limiting factor for CCE, the chemical erosion is 10 times higher for carbonate than for silicate. The average chemical erosion rate obtained for large Himalayan rivers (Table $8)$ is similar to that of Andean rivers for silicate $(0.007 \mathrm{~mm} / \mathrm{yr}$; Gaillardet et al., 1997) but 4 to 5 more important for carbonate. A higher proportion of limestone in the Himalayan terranes is likely to explain this difference.

In Bangladesh, the Brahmaputra shows chemical erosion rates very similar to those of the Tista or Trisuli. This is consistent with the Himalayan character of the river and the relatively low proportion of carbonates in the non-Tibetan part of the watershed. The Ganges displays significantly lower chemical erosion rates, compared to Himalayan rivers, especially for carbonates (Table 8). The chemical flux of the Ganges plain, calculated as the difference between Ganges and the sum of the Himalayan and southern tributaries (Table 9), allows us to estimate SCE and CCE for the flood plain at 0.001 and $0.004 \mathrm{~mm} / \mathrm{yr}$ respectively. The Gomti river (Subramanian et al., 1987; Sarin et al., 1989), which drains only the central Ganges flood plain, also has low SCE and CCE ( 0.003 and $0.009 \mathrm{~mm} / \mathrm{yr}$, respectively). The very low CCE in the plain may result from the relatively low amount of carbonate available for dissolution. Our analyses of the Ganges bedload in Bangladesh shows that it contains ca. $6 \mathrm{wt} \%$ of detrital carbonate. Thus much less carbonate is exposed to dissolution in the flood plain than in the Himalaya. Low SCE and CCE may also result from drier conditions in the plain than in the Himalayan part of the basin. For the entire dry season, the atmospheric water balance is negative in a large part of the plain, which behaves almost as an endoreic system. Such dry conditions are responsible for the development of alkaline soils (Sarin et al., 1989). Over one year, intense evapotranspiration in the plain results in an effective discharge of only 0.4 to $1 \mathrm{~m} / \mathrm{yr}$, despite precipitation between 1 and $2 \mathrm{~m} / \mathrm{yr}$ (Henning, 1989).

The low SCE is however somewhat contradictory with the increase of the smectite and kaolinite proportion in the clay fraction of suspended load along the Ganges course measured by Sarin et al. (1989). This apparent discrepancy may results from a hidden flux of dissolved elements in the system. Based on a study of radium and barium fluxes, Moore (1997) has shown that there is an active submarine discharge of ground water at the G-B mouth. While the magnitude of the water flux is not accurately known it could be between 0.35 to 3.5 time that of the rivers. Since ground waters have higher concentrations of dissolved species than river water, this may imply a notable flux of 
dissolved elements. The hydrological budget of the Ganges system supports this hypothesis. The runoff for the Ganges plain calculated from the difference of the Ganges flux at the mouth and the sum of all its major tributaries collected from hydrological data (Rao, 1979; Hossain et al., 1987; Alford, 1992; Dept. of Hydrology and Meteorology, unpub. data) is ca. $0.3 \mathrm{~m} / \mathrm{yr}$. Such value is significantly lower than the average discharge ( 0.4 to $1 \mathrm{~m} / \mathrm{yr}$ ) calculated as the difference between precipitation and evapotranspiration (Henning, 1989). Uncertainties remain, but several independent evidences suggest a possibility of significant ground water flux at the G-B mouth.

\subsection{Long term $\mathrm{CO}_{2}$ atmospheric uptake by the Ganges-Brahmaputra system}

The alkalinity flux carried by the G-B rivers corresponds to $3.7 \%$ of the world riverine flux to the ocean according to Berner and Berner (1996). This value is higher than the fresh water flux ( $2.8 \%$ of the global) and suggests a high weathering rate in GB. Lithology is a key parameter controlling weathering rate (Meybeck, 1987), and the ubiquitous occurrence of carbonates from the north flank of the Himalaya in the sands in Bangladesh controls the TDS. With regard to long term $\mathrm{CO}_{2}$ uptake, only the alkalinity flux linked to silicate weathering is important. For the combined G-B flux, the fraction of cationic charge derived from silicate weathering is ca. $23 \%$. We estimate that ca. $70 \%$ of the sulfate flux of the G-B derives from the oxidation of pyrite in the Himalaya (the remaining sulfate being derived from cyclic salts and from Indian shield tributaries). The exact proportion of silicate and carbonate altered by sulphuric acid instead of $\mathrm{CO}_{2}$ is difficult to estimate, but clearly a significant fraction of the cationic charge derived from silicate alteration is balanced by $\mathrm{SO}_{4}{ }^{2-}$ rather than $\mathrm{HCO}_{3}{ }^{-}$, and thus does not contribute to the alkalinity. If all of the sulfide-derived sulfate reacted with silicates, the silicate alkalinity flux would be $1.40 \times 10^{11} \mathrm{~mol} / \mathrm{yr}$. If this sulfuric acid reacted only with carbonates, the silicate alkalinity flux would be $2.95 \times 10^{11} \mathrm{~mol} / \mathrm{yr}$. Assuming that sulphuric acid weathers carbonate and silicate in the same proportion as the $\mathrm{CO}_{2}$ does, the silicate alkalinity flux is around $2.66 \times 10^{11} \mathrm{~mol} / \mathrm{yr}$.

The silica flux may also be used to estimate the alkalinity flux linked to the silicate weathering (Edmond et al., 1996) while in areas of high physical erosion it may be an underestimate. The G-B silica flux would suggest a silicate alkalinity flux of $2.73 \times 10^{11}$ $\mathrm{mol} / \mathrm{y}$, in the range of our estimates. These estimates would correspond to $2.3 \%$ of the global riverine silicate alkalinity flux (Berner and Berner, 1996; Ludwig et al., 1996). Weathering in the G-B basin appears less efficient as a sink of atmospheric $\mathrm{CO}_{2}$ than in other tropical-equatorial basins, such the Amazon and the Congo (Edmond et al., 1996; 
Gaillardet et al, 1995). Additionally, 60 to $65 \%$ of the silicate alkalinity in the G-B is balanced by $\mathrm{Na}^{+}$and $\mathrm{K}^{+}$. This is close to, but slightly lower than, the estimate established from the chemical difference between $\mathrm{HHC}$ and eroded sediments (FranceLanord and Derry, 1997). Only a part of $\mathrm{Na}^{+}$and $\mathrm{K}^{+}$is exchanged for $\mathrm{Ca}^{2+}$ in the marine environment, allowing alkalinity to precipitate as carbonate. The rest undergoes reverse weathering reactions which return alkalinity to the atmosphere. The effectiveness of these processes is poorly constrained, but assuming that $20 \%$ of $\mathrm{K}^{+}$and $30 \%$ of $\mathrm{Na}^{+}$ are exchanged for $\mathrm{Ca}^{2+}$ (France-Lanord and Derry, 1997), the modern $\mathrm{CO}_{2}$ consumption by Ganges and Brahmaputra would be around $6.4 \times 10^{10} \mathrm{~mol} / \mathrm{yr}$. Using the same assumptions, the global uptake of atmospheric $\mathrm{CO}_{2}$ by silicate weathering calculated from river chemical data should be around $48.5 \times 10^{11} \mathrm{~mol} / \mathrm{yr}$ (Berner and Berner, 1996). Thus, with $1.3 \%$ of the global long term $\mathrm{CO}_{2}$ uptake, the $\mathrm{G}-\mathrm{B}$ basin appears to be a minor control on atmospheric $\mathrm{pCO}_{2}$. In the reality, the G-B $\mathrm{CO}_{2}$ uptake is likely to be higher if the probable flux of ground water to the ocean is taken into account. This flux remains to be accurately estimated. However, the low rate of $\mathrm{CO}_{2}$ uptake in the G-B basin is, in part, the result of a very low proportion of Ca- and $\mathrm{Mg}$-silicates in Himalaya and this will apply also to the ground water.

\section{Conclusion}

The G-B river system is remarkable for the diversity of erosion and weathering regimes active in its different parts. From Tibet to the flood plain the influence of the tectonic processes, lithology of eroded terranes, and climate all contribute to the final chemical signature of the G-B waters.

Himalayan tectonic activity affects chemical weathering in several ways. First, the high rate of uplift in the High Himalaya develops steep relief and high elevation surfaces. These terranes are therefore undergoing rapid physical erosion instead of slow processes of soil development. Himalayan tectonics acts in this case as a limiting factor for chemical erosion. Second, in the southern part of Tibet, extentional grabens degas metamorphic $\mathrm{CO}_{2}$. Dissolved in ground water, this $\mathrm{CO}_{2}$ is an important source of carbonic acid for weathering in the northern basins. At the G-B scale, their contribution is nevertheless negligible, of the order of $10^{10} \mathrm{~mol} / \mathrm{yr}$. Third, development of the foreland basin at the front of the range (e.g. Burbank, 1992) accumulates silty material in the flood plains that favours circulation of the ground water. This region is likely dominated by silicate weathering reactions, such as these observed in the rivers draining the Siwaliks. Flood plain ground water may represent a significant flux toward the 
ocean, as proposed by Moore (1997). However, this flux remains to be quantified for major dissolved elements.

The main lithologic parameters are the presence of carbonate, in the TSS, the presence of sulfides, and the composition of silicate rocks. Carbonate units overprint the chemical riverine signature form north to south. Despite the fact that they are mostly exposed in zones of high altitude and low precipitation, carbonates are the main source of dissolved elements. Cations derived from carbonate dissolution represent 80 to $90 \%$ of the total cationic charge in all parts of the basin, except in purely silicate drainage. The presence of sulfide plays an important role as weathering agent. Sulphuric acid derived from sulfide oxidation results in a high rate of weathering in places where low precipitation and temperature do not favour chemical weathering. Overall, sulphuric acid controls $20-30 \%$ of the weathering reactions in the Brahmaputra and 6 to $9 \%$ in the Ganges. The high level of oxidized sulfide in the G-B is likely accompanied by release of PGE. They therefore represent a potential source of radiogenic Os in the Himalayan erosion as inferred by Pegram et al. (1992). Finally, the dominantly alkaline composition of Himalayan silicate rocks implies that most of the cations released by silicate weathering are $\mathrm{Na}^{+}$and $\mathrm{K}^{+}$. Because these cations exchange incompletely with $\mathrm{Ca}^{2+}$ and $\mathrm{Mg}^{2+}$ to precipitate carbonate, this reduces the potential uptake of atmospheric $\mathrm{CO}_{2}$ by Himalayan silicate weathering. Despite a relatively important flux of alkalinity, the overall long term $\mathrm{CO}_{2}$ uptake related to modern Himalayan erosion appears minor on the global scale.

The climate controls the weathering style and intensity. To the north of the high range, the arid and cold climate does not favour soil development. Weathering reactions are therefore dominated by inorganic processes driven by sulfide oxidation or by carbonic acid derived from metamorphic degassing. We do not have a yearly average of dissolved fluxes for the Upper Kali Gandaki, but the estimated rate of chemical erosion is between 0.02 and $0.05 \mathrm{~mm} / \mathrm{yr}$, low for a carbonate rich basin. On the southern flank of the range, heavy rainfall and tropical temperatures enable development of soils and vegetative cover up to $4000 \mathrm{~m}$ altitudes. In these basin, weathering reactions are dominantly driven by carbonic acid derived from biologic activity in the soils. Under these conditions, the rate of chemical erosion reaches $0.005 \mathrm{~mm} / \mathrm{yr}$ for silicates and $0.06 \mathrm{~mm} / \mathrm{yr}$ for carbonates. In the flood plain, despite heavy monsoonal rainfall, high temperature and favourable physical conditions (flat soils and alluvial material), the rate of chemical erosion appears lower than in the Himalaya. The low rates may result from the atmospheric water balance which is strongly influenced by evapotranspiration, and dry conditions prevail in the plain for large parts of the year. At the G-B scale, differences appear between the two river system. The Brahmaputra basin is exposed to more intense monsoon than the Ganges, as 
shown by their respective runoffs of 1090 (Brahmaputra) and $617 \mathrm{~mm} / \mathrm{yr}$ (Ganges). The rate of chemical erosion for each system are similar, but this is difficult to interpret because the geographic and geologic distribution of surface area in the two basins are very different. More meaningful are (1) the mineralogical composition of the clay fraction in the sediment load with smectite+kaolinite around $20 \%$ for Brahmaputra and $60 \%$ for Ganges, and (2) the ratio of physical to chemical flux, which is 9.3 for Brahmaputra and 3.9 for the Ganges. These data clearly show that erosion in the Brahmaputra basin is more influenced by physical processes when compared to the Ganges. From this comparison, the monsoonal climate appears to be the limiting factor for weathering as it favours rapid physical erosion and transport.

\section{Acknowledgements}

This work would have been impossible without the sampling assistance of number of Himalayan geologists: A. Gajurel, P. Le Fort, J-L. Mugnier, B. Marty, R. Muralt, and the "MO" team. We greatly thank the analytical assistance of P. Coget, O. Gabens, B. Jacquier, E. F. Rose and M. Vernet. We also thank Prof. B.N. Upreti for his constant help during this project in Nepal. The collaboration of M. D. Shafiqul Alam from the department of Archeology of Bangladesh and K. Pedoja under the auspices of "la mission d'Orient" made sampling in Bangladesh possible. This paper has benefited from fruitful discussion with L. A. Derry and P. Le Fort, and from reviews by S. Krishnaswami, M. R. Palmer and J. Veizer. This work was supported by the CNRSINSU programs DBT "Fleuves et Érosion" and PROSE. A. G. was supported by a CNRS-Région Lorraine grant during this study. CNRS-INSU-DBT contribution \# XXXX and CRPG-CNRS contribution \# 1340. 


\section{References}

Alford D., 1992. Hydrological aspects of the Himalayan region. ICIMOD Occasional paper No. 18.

Bartarya S. K., 1993. Hydrochemistry and rock weathering in a sub-tropical Lesser Himalayan river basin in Kumaun, India. Journal of Hydrology, 146: 149-174.

Bäumler, R. and Zech, W. 1994. Soils of the high mountain region of Eastern Nepal: classification, distribution and soil forming processes. Catena, 22: 85-103.

Berner, R. A. and Berner, E., 1996. Global Environment : Water, Air, and Geochemical Cycles. Prentice Hall.

Blum, J. D., Gazis, C. A., Jacobson ,A. D., and Chamberlain, C. P., 1998. Carbonate versus silicate weathering in the Raikhot watershed within the High Himalayan Crystalline Series. Geology, 26: 411-414.

Bordet, P., Colchen, M., Krummenacher, D., Le Fort, P., Mouterde, R. and Remy, M., 1971. Recherches Géologiques dans l'Himalaya du Népal, Région de le Thakkhola. Centre National de la Recherche Scientifique.

Brouand, M., 1989. Pétrogenese des migmatites de la dalle du Tibet (Himalaya du Népal). Ph.D. Thesis, INPL, Nancy, France.

Burbank, D. W., 1992. Causes of recent Himalayan uplift deduced from deposited patterns in the Ganges basin. Nature, 357: 680-683.

Cerling, T. E., Quade, J., Wang, Y. and Bowman, J. R., 1989. Carbon isotopes in soils and palaeosols as ecology and palaeoecology indicators. Nature, 341: 138-139.

Chillrud, S. N., Pedrozo, F. L., Temporetti, P. F., Planas, H. F. and Froelich, P. N., 1994. Chemical weathering of phosphate and germanium in glacial meltwater streams: Effects of subglacial pyrite oxidation. Limnology and Oceanography, 39: 1130-1140.

Colchen, M., Le Fort, P. and Pêcher, A., 1986. Notice explicative de la carte géologique AnnapurnaManaslu-Ganesh (Himalaya du Népal) au 1:200.000e (bilingue: français-english). Centre National de la Recherche Scientifique.

Collins, R. and Jenkins, A., 1996. The impact of agricultural land use on stream chemistry in the Middle Hills of the Himalayas, Nepal. Journal of Hydrology, 185, 71-86.

Derry, L. A. and France-Lanord, C., 1996. Neogene Himalayan weathering history and river ${ }^{87} \mathrm{Sr} /{ }^{86} \mathrm{Sr}$ : Impact on the marine Sr record. Earth and Planetary Science Letters, 142: 59-74.

Edmond, J. M., Palmer, M. R., Measures, C. I., Brown, E. T. and Huh, Y., 1996. Fluvial geochemistry of the eastern slope of the northeastern Andes and its foredeep in the drainage of the Orinoco in Colombia and Venezuela. Geochimica et Cosmochimica Acta, 60: 2949-2976.

Fairchild, I. J., Bradby, L., Sharp, M. and Tison, J.-L., 1994. Hydrochemistry of carbonate terrains in alpine glacial settings. Earth Surface Processes and Landforms, 19: 33-54.

Fontes, J.-C., Gasse, F. and Gilbert, E., 1996. Holocene environmental changes in Lake Bangong basin (Western Tibet). Part 1: Chronology and stable isotopes of carbonates of a Holocene lacustrine core. Palaeogeography, Palaeoclimatology, Palaeoecology, 120: 25-47.

Fort, M., 1996. Late Cenozoic environmental changes and uplift on the northern side of the central Himalaya: a reappraisal from field data. Palaeogeography Palaeoclimatology Palaeoecology, 120: $123-145$.

France-Lanord, C., 1987. Chevauchement, métamorphisme et magmatisme en Himalaya du Népal central. Etude isotopique H, C, O. Ph.D. Thesis, INPL, Nancy, France.

France-Lanord, C. and Le Fort, P., 1988. Crustal melting and granite genesis during the Himalayan collision orogenesis. Transactions of the Royal Society of Edinburgh Earth Sciences, 79: 183-195.

France-Lanord, C. and Derry, L. A., 1997. Organic carbon burial forcing of the carbon cycle from Himalayan erosion. Nature, 390: 65-67.

France-Lanord, C., Derry, L. A., Le Fort, P., Mugnier, J.-L. and Gajurel, A. P., 1995. Silicate and carbonate weathering in the high Himalaya: Chemistry, $\mathrm{C}$ and $\mathrm{Sr}$ isotopic composition of the river system of Central Nepal., V. M. Goldschmidt Conference, 46.

Friedman, I. and O'Neil, J. R., 1977. Compilation of stable isotope fractionation factors of geochemical interest. In Data of Geochemistry, Vol. 440 - K.K. (ed. M. Fleischer), pp. 1-114. Geological Survey.

Gaillardet, J., Dupré, B. and Allègre, C. J., 1995. A global geochemical mass budget applied to the Congo Basin rivers: Erosion rates and continental crust composition. Geochimica et Cosmochimica Acta, 59, 3469-3485.

Gaillardet, J., Dupré, B., Allègre, C. J. and Négrel, P., 1997. Chemical and physical denudation in the Amazon river basin. Chemical Geology, 142: 141-173.

Galy, A., France-Lanord, C. and Derry, L. A., submitted. The Strontium isotopic budget of Himalayan rivers in Nepal and Bangladesh.

Gansser, A., 1964. Geology of the Himalayas. Intersciences Publishers, L.U. 
Goddéris, Y. and François, L. M., 1996. Balancing the Cenozoic carbon and alkalinity cycles: Constraints from isotopic records. Geophysical Research Letters, 23: 3743-3746.

GRDC, 1994. Hydrological Regimes of the 20 largest rivers of the Wold - A compilation of the GRDC Database - No. 5. Global Runoff Data Centre.

Grout, H., 1995. Caractérisation physique, minéralogique, chimique et signification de la charge particulaire et colloïdale de rivières de la zone subtropicale. Ph.D. Thesis, Aix-Marseille, France.

Handa, B. K., 1969. Chemical composition of monsoon rains over Calcutta. Part I. Tellus, 22: 95-100.

Handa, R. K., 1972. Geochemistry of the Ganga River Water. Indian Geohydrology, 2: 71-78.

Harris, N., Bickle, M., Chapman, H., Fairchild, I., and Bunbury, J., 1998. The significance of Himalayan rivers for silicate weathering rates: evidence from the Bhote Kosi tributary. Chemical Geology, 144: 205-220.

Hasnain, S. I. and Thayyen, R. J., 1996. Sediment transport and solute variation in meltwaters of Dokriani glacier (Bamak), Garhwal Himalaya. Journal Geological Society of India, 47: 731-739.

Henning, D., 1989. Atlas of the surface heat balance of the continents. Gebrüder Borntraeger.

Hossain, M., Aminul Islam, A. T. M. and Kumar Saha, S., 1987. Floods in Bangladesh. Universities Research Centre.

Hurtrez, J.-E., 1998. Analyse géomorphologique des interactions Tectonique-Erosion dans le système Himalayen. Ph.D. Thesis, Montpellier, France.

Krishnamurthy, R. V. and Bhattacharya, S. K., 1991. Stable oxygen and hydrogen isotope ratios in shallow ground waters from India and a study of the role of evapotranspiration in the Indian monsoon. In H. P. Taylor, J. R. O'neil, \& I. R. Kaplan (Eds.), Stable isotope Geochemistry : a tribute to Samuel Epstein (pp. 187-193). Geochemical Society.

Krishnaswami, S., Trivedi, J. R., Sarin, M. M., Ramesh, R. and Sharma, K. K., 1992. Strontium isotopes and rubidium in the Ganga-Brahmaputra river system: Weathering in the Himalaya, fluxes to the Bay of Bengal and contributions to the evolution of oceanic ${ }^{87} \mathrm{Sr} /{ }^{86} \mathrm{Sr}$. Earth and Planetary Science Letters: 109: 243-253.

Le Fort, P., 1989. The Himalayan orogenic segment. In A. M. C. Sengör (Eds.), Tectonic evolution of the Tethyan regions. Proceedings of the NATO ASI meeting, Istanbul, October 1985. Reidel Publ. Co.

Le Fort, P. and France-Lanord, C., 1995. Granites from Mustang and surrounding regions. Journal of Nepal Geological Society, 11: 53-57.

Ludwig, W., Amiotte-Suchet, P. and Probst, J.-L., 1996. River discharges of carbon to the world's oceans: determining local inputs of alkalinity and of dissolved and particulate organic carbon. Compte Rendu de l'Académie des Sciences, 323: 1007-1014.

Mc Cauley, S. E. and De Paolo, D. J, 1997. The marine ${ }^{87} \mathrm{Sr} /{ }^{86} \mathrm{Sr}$ and $\delta^{18} \mathrm{O}$ records, Himalayan Alkalinity fluxes, and Cenozoic climate Models. in W.In W. F. Ruddiman (Eds.), Uplift and Climate Change (pp. ). New York: Plenum Press.

Meybeck, M., 1987. Global chemical weathering of surficial rocks estimated from river dissolved loads. American Journal of Science, 287: 401-428.

Mook, W. G. and Tan, F. C., 1991. Stable Carbon Isotopes in Rivers and Estuaries. In E. T. Degens, S. Kempe, \& J. E. Richey (Eds.), Biogeochemistry of Major World Rivers (pp. 245-264). John Wiley \& Sons Ltd.

Mook, W. G., Bommerson, J. C. and Staverman, W. H., 1974. Carbon isotope fractionation between dissolved bicarbonate and gaseous carbon dioxide. Earth and Planetary Science Letters, 22: 169-176.

Moore, W. S., 1997. High fluxes of radium and barium from the mouth of the Ganges-Brahmaputra River diring low river discharge suggest a large groundwater source. Earth and Planetary Science Letters, 150: 141-150.

Négrel, P., Allègre, C. J., Dupré, B., and Léwin, E., 1993. Erosion sources determined by inversion of major and trace element ratios and strontium isotopic ratios in river water: the Congo basin case. Earth and Planetary Science Letters, 120: 59-76.

Palmer, M. R. and Edmond, J. M., 1992. Controls over the strontium isotope composition of river water. Geochimica et Cosmochimica Acta, 56: 2099-2111.

Pawellek, F. and Veizer, J., 1995. Carbon cycle in the upper Danube and its tributaries: $\delta^{13} C_{\text {DIC }}$ constraints. Israel Journal of Earth Sciences, 43: 187-194.

Pêcher, A., 1978. Déformation et métamorphisme associés à une zone de cisaillement. Exemple du grand chevauchement central himalayen (M.C.T.), transversale des Annapurnas et du Manaslu, Népal. Ph.D. Thesis, Joseph Fourier Univ., Grenoble, France.

Pegram, W. J., Krishnaswami, S., Ravizza, G. E. and Turekian, K. K., 1992. The record of sea water ${ }^{187} \mathrm{Os} /{ }^{186} \mathrm{Os}$ variation through the Cenozoic. Earth and Planetary Science Letters, 113: 569-576.

Quade, J., Roe, L., DeCelles, P. G. and Ojha, T. P., 1997. The late Neogene $87 \mathrm{Sr} / 86 \mathrm{Sr}$ record of lowland Himalayan rivers. Science, 276: 1828-1831.

Rao, K. L., 1979. India's water wealth. Orient Longman limited. 
Raymo, M. E. and Ruddiman, W. F., 1992. Tectonic forcing of late Cenozoic climate. Nature, 359: 117 122.

Richter, F. M., Rowley, D. B. and DePaolo, D. J., 1992. Sr isotope evolution of seawater: the role of tectonics. Earth and Planetary Science Letters, 109: 11-23.

Sarin, M. M. and Krishnaswami, S., 1984. Major ion chemistry of the Ganga-Brahmaputra river systems, India. Nature, 312: 538-541.

Sarin, M. M., Krishnaswami, S., Dilli, K., Somayajulu, B. L. K. and Moore, W. S., 1989. Major ion chemistry of the Ganga-Brahmaputra river system: Weathering processes and fluxes to the Bay of Bengal. Geochimica et Cosmochimica Acta, 53: 997-1009.

Sarin, M. M., Krishnaswami, S., Trivedi, J. R. and Sharma, K. K., 1992. Major ion chemistry of the Ganga source Waters : Weathering in the high altitude Himalaya. Earth and Planetary Science, 101: 89 - 98.

Seeber, L. and Gornitz, V., 1983. River profiles along the Himalayan arc as indicators of active tectonics. Tectonophysics, 92: 335-367.

Shieh, Y.N. and Taylor, H.P., 1969. Oxygen and carbon isotope studies of contact metamorphism of carbonate rocks. Journal of Petrology, 10: 307-331.

Sequeira, R. and Kelkar, D., 1978. Geochemical implications of summer monsoonal rainwater composition over India. Journal of Applied Meteorology, 17: 1390-1396.

Singh, S. K., Trivedi, J. R., Pande, K., Ramesh, R. and Krishnaswami, S., 1998. Chemical and Sr, O, $\mathrm{C}$, isotopic compositions of carbonates from the Lesser Himalaya: Implications to the $\mathrm{Sr}$ isotope composition of the source waters of the Ganga, Ghaghara and the Indus Rivers. Geochimica et Cosmochimica Acta, 62: 743-755.

Solomon, D. K. and Cerling, T. E., 1987. The annual Carbon Dioxide Cycle in a Montane Soil: Observations, Modeling, and Implications for weathering. Water Resources Research, 23: 2257-2265.

Subramanian, V., Sitasawad, R., Abbas, N. and Jha, P. K., 1987. Environmental Geology of the Ganga River Basin. Journal Geological Society of India, 30: 335-355.

Tsunogai, S., Saito, O., Yamada, K. and Nakaya, S., 1972. Chemical composition of oceanic aerosol. Journal of Geophysical research, 77: 5283-5292.

Upreti, B. N. and Le Fort, P., in press.. Lesser Himalayan crystalline nappes of Nepal: problems of their origin. In A. Macfarlane, R. B. Sorkhabi, \& J. Quade (Eds.), Himalaya and Tibet: mountain roots to mountain tops. GSA special paper $\mathrm{N}^{\circ} 328$.

Vennum, W. R., 1980. Evaporite encrustations and sulfide oxidation products from the southern Antartic Peninsula. New Zealand Journal of Geology and Geophysics, 23: 499-505.

Wake C. P., Mayewski, P. A. and Spencer, M. J., 1990. A review of central Asian glaciochemical data. Annals of Glaciology, 14: 301-306.

Wake, C. P., Mayewski, P. A., Zichu, X., Ping, W. and Zhongqin, L., 1993. Regional distribution of monsoon and desert dust signals recorded in Asian glaciers. Geophysical Research Letters, 30: 14111414.

Williams, M. W., Yang, D., Liu, F., Turk, J. and Melack, J. M., 1995. Controls on the major ion chemistry of the Urumqi River, Tian Shan, People's Republic of China. Journal of Hydrology, 172: 209-229. 


\section{Figure captions}

Fig. 1 : Map of the Ganges and Brahmaputra basin and location of river samples and maps of figure 2 . When several samples were taken at the same location only the first sample is labelled on the map. MFT: Main frontal thrust is the southernmost Himalayan thrust, thrusting the Siwaliks over the Gangetic plain. MCT : Main Central Thrust, thrusting the High Himalaya Crystalline over the Lesser Himalaya, is mostly located at the foot of the high range (Seeber and Gornitz, 1983).

Fig. 2 : Geological maps of Narayani watershed (a) and Karnali watershed (b) with water samples. When several samples have been taken at the same location only the first sample is labelled on the map. Geology after Colchen et al. (1986); Le Fort and FranceLanord (1995) and Upreti and Le Fort (in press). TSS = Tethian Sedimentary Series. HHC $=$ High Himalaya Crystalline. LH $=$ Lesser Himalaya. HHL $=$ High Himalaya Leucogranite. LHN = Lesser Himalaya Nappe.

Fig. 3 : Triangular plots representing the relative abundance of major cation and anion charges. $\mathrm{Ca}$ is the dominant cation and $\mathrm{Mg}$ remains low in silicate drainage. $\mathrm{SO}_{4}{ }^{2-}$ typically represents 10 to $20 \%$ of the anion charge. $\mathrm{Cl}^{-}$is only significant in rivers draining the Mustang graben conglomerate.

Fig. 4 : River profile of the Kali Gandaki, from the source above Lo Mantang (Mustang) to the outflow of the Narayani in the Gangetic plain. a) Topographic profile of the river and average crest altitude (Hurtrez,1998). The breaks in the slope of the river profile underline the zones of intense physical erosion. Rocks of the Tethian sedimentary series (TSS) are separated from the High Himalayan Crystalline (HHC) by the Southern Tibetan Detachment System (STDS). The HHC are thrust over the Lesser Himalaya (LH) along the Main Central Thrust (MCT). b) average precipitation over the river basin from kriging of meteorological data of Nepal (Hurtrez,1998). c) Total Dissolved Solid (TDS). d) $\delta^{13} \mathrm{C}_{\mathrm{DIC}}$ decreases from north to south. In the north $\delta^{13} \mathrm{C}_{\mathrm{DIC}} \approx 0 \%$, implying an inorganic origin of the carbon, while to the south, soil respiration becomes important. e) The ratio of sulfate to bicarbonate $\left(\mathrm{X}_{\mathrm{SO}_{4}}\right)$ that largely reflects the contribution of the southern part of the TSS in this basin. $\mathrm{f})$ silicate to carbonate weathering ratio $\left(\mathrm{X}_{\mathrm{Sil}}\right)$ as defined in appendix.

Fig. 5 : Isotopic composition of dissolved inorganic carbon $\left(\delta^{13} \mathrm{C}_{\text {DIC }}\right)$ versus ratio of $\left[\mathrm{SO}_{4}{ }^{2-}\right]$ over $\left(\left[\mathrm{SO}_{4}{ }^{2-}\right]+\left[\mathrm{HCO}_{3}-\right]\right)$ termed $\left(\mathrm{X}_{\mathrm{SO}_{4}}\right)$. Curves describe water characteristics for alteration driven by variable mixtures of sulphuric acid and carbonic acid of biologic 
origin. Curves are drawn for different proportions of altered silicate to carbonate, assuming that both mineral are altered in the same amount by each acid. $\delta^{13} \mathrm{C}$ of carbonate $=0 \%, \delta^{13} \mathrm{C}$ of soil $\mathrm{CO}_{2}=-18 \%$.

Fig. 6a : Plot of $\delta^{13} \mathrm{C}_{\mathrm{DIC}}$ versus $\mathrm{X}_{\mathrm{SO}_{4}}$ in the Kali Gandaki head waters. Data for thermal springs sampled near the river show high $\delta^{13} \mathrm{C}$ values, implying a metamorphic origin for the $\mathrm{CO}_{2}$. The mixing curve corresponds to the alteration by sulphuric acid and respired carbonic acid of $70 \%$ of carbonate and $30 \%$ of silicate. The fact that rivers plot to the right of the mixing curve implies that $\mathrm{CO}_{2}$ rich in ${ }^{13} \mathrm{C}$ is involved in the alteration reaction in addition to biologic $\mathrm{CO}_{2}$. The contribution of metamorphic $\mathrm{CO}_{2}$ dissolved in ground water as sampled in thermal springs is clearly identified at several locations.

Fig. 6b : Plot of $\delta^{13} \mathrm{C}_{\mathrm{DIC}}$ versus $\mathrm{X}_{\mathrm{SO}_{4}}$ for main Himalayan rivers, Ganges and Brahmaputra. The mixing trend corresponds to the alteration by sulphuric acid and biologic carbonic acid of $70 \%$ of carbonate and $30 \%$ of silicate. Most samples are compatible with a model of alteration driven by soil $\mathrm{CO}_{2}$ mixed with variable proportion of $\mathrm{H}_{2} \mathrm{SO}_{4}$. The 3 labelled samples are close to the MCT, where spring waters are known and may locally influence the TDS.

Fig. 7 : Seasonal variation of the water discharge and chemistry of the Trisuli river at Betrawati for TDS, $\mathrm{X}_{\mathrm{SO}_{4}}, \mathrm{X}_{\mathrm{Sil}}$ and $\delta^{13} \mathrm{C}_{\mathrm{DIC}}$. The shaded area corresponds to the monsoon season. Water discharge data are from the Dept. of Hydrology and Meteorology of Nepal.

Fig. 8 : Seasonal variation of TDS versus $\mathrm{XSO}_{4}$ for the Trisuli river at Betrawati. The lowest TDS values occur at the beginning and end of the monsoon. The lowest $\mathrm{XSO}_{4}$ values are found during the peak monsoon, while the highest $\mathrm{XSO}_{4}$ occur during the dry season.

Fig. 9 : $\mathrm{K}^{*}$ versus $\mathrm{Mg} *$ concentration relationship for Himalayan rivers. Concentrations have been corrected for cyclic contribution according to $\S 5.1$. Open symbols: rivers draining carbonate and silicate formations; Grey symbols: rivers draining only silicate formations. The line represents $[\mathrm{Mg}]^{*} /[\mathrm{K}]^{*}$ ratios of 1 . Some samples with extreme concentrations have been excluded. The data show that silicate weathering contributes a small fraction of the dissolved $\mathrm{Mg}$ budget in most rivers. 


\section{Appendix : Definition of the $\mathbf{X}_{\text {sil }}$}

Assuming negligible anthropogenic contributions for major rivers, and correcting for cyclic contribution (cf. § 5.1), equation (1) can be simplified in the equation (2) : $[\mathrm{X}]_{\text {river }}=\mathrm{X}_{\text {cyclic }}+\mathrm{X}_{\text {evaporite }}+\mathrm{X}_{\text {carbonate }}+\mathrm{X}_{\text {silicate }}+\mathrm{X}_{\text {sulfide }}+\mathrm{X}_{\text {anthropogenic }}$ (1) $[\mathrm{X}]^{*}$ river $=\mathrm{X}_{\text {evaporite }}+\mathrm{X}_{\text {carbonate }}+\mathrm{X}_{\text {silicate }}+\mathrm{X}_{\text {sulfide }}$

Our modelling is based on four straightforward simplifications of the budget equations. First, chloride is only derived from evaporites and from precipitation. Second, the dissolution of carbonate does not contribute to the dissolved sodium and potassium. Third, evaporite weathering yields only $\mathrm{NaCl}$. Finally, sulfate is entirely derived from sulfide oxidation. With these assumptions, we can simplify the equation (1) as follows :

$$
\begin{aligned}
& {[\mathrm{Cl}]^{*}=\mathrm{Cl}_{\text {evaporite }}} \\
& {[\mathrm{Na}]^{*}=\mathrm{Cl}_{\text {evaporite }}+\mathrm{Na}_{\text {silicate }}} \\
& {\left[\mathrm{SO}_{4}\right]^{*}=\mathrm{SO}_{4 \text { sulfide }}} \\
& {[\mathrm{K}]^{*}=\mathrm{K}_{\text {silicate }}} \\
& {[\mathrm{Ca}]^{*}=\mathrm{Ca}_{\text {carbonate }}+\mathrm{Ca}_{\text {silicate }}} \\
& {[\mathrm{Mg}]^{*}=\mathrm{Mg}_{\text {carbonate }}+\mathrm{Mg}_{\text {silicate }}}
\end{aligned}
$$

Equations (7) and (8) are difficult to solve because of the uncertainty about silicate versus carbonate contributions. In most river system, $\mathrm{Sr}$ isotopic composition is a useful additional constraint, but in the case of Himalayan rivers the $\mathrm{Sr}$ isotopic budget is complex and cannot be used for this purpose (Palmer and Edmond, 1992; Krishnaswami et al., 1992; Blum et al., 1998; Harris et al., 1998; Singh et al., 1998). Chemical composition of the eroded rocks is therefore utilized as the substitute criterion. The Himalayan crust is dominated by quartz, $\mathrm{K}$ and $\mathrm{Na}$ feldspars, and micas. Calcic silicates are not a major source of eroded material, except in the Formation II of the HHC (Colchen et al. 1986). A maximum estimate for the $\mathrm{Ca} / \mathrm{Na}$ ratio of silicates is given by the mean whole-rock composition of the eroded formations. These are 0.25 for the HHC (France-Lanord and Derry, 1997), 0.30 for the LH (Pêcher, 1978) and 0.06 for leucogranitic rocks (France-Lanord and Le Fort, 1988). A minimum ratio is given by the analyses of plagioclase in the $\mathrm{HHC}$ of central Nepal, with an average $\mathrm{Ca} / \mathrm{Na}$ ratio of 0.18 (Brouand, 1989). On this basis we consider that the $\mathrm{Ca} / \mathrm{Na}$ ratio delivered to the dissolved load must be close to 0.2 which allows us to rewrite equation (7) where all species are in $\mu \mathrm{mol} / \mathrm{l}$ :

$$
[\mathrm{Ca}]^{*}=\mathrm{Ca}_{\text {carbonate }}+\mathrm{Na}_{\text {silicate }} \times 0.2
$$

The budget of $\mathrm{Mg}$ is more difficult to assess. Dolomite is present in all bed load samples, except in the Upper Kali Gandaki basin, and therefore an unknown proportion 
of $\mathrm{Mg}$ is derived from carbonate. Marked positive relationship between [Ca] and $[\mathrm{Mg}]$ suggest that a large proportion of the $\mathrm{Mg}$ is derived from dolomite weathering. On the silicate side, the main reaction which can release $\mathrm{Mg}$ in Himalaya is the weathering of biotite and, to a lesser extent, chlorite and garnet. These reactions are incongruent and $\mathrm{Mg}$ is retained in weathering by products such as hydrobiotite, vermiculite or smectite, all common in the Himalayan soils (Bäumler and Zech, 1994; Grout, 1995). The $\mathrm{Mg}_{\text {silicate }}$ contribution can be estimated using the $[\mathrm{Mg}]^{*}$ versus $[\mathrm{K}]^{*}$ relationship (Fig 9). In this diagram, rivers draining both carbonate and silicate formations have $[\mathrm{Mg}]^{*} /[\mathrm{K}]^{*}$ ratios above 1 , and $[\mathrm{Mg}]^{*}$ appears to be independent of $[\mathrm{K}]^{*}$. In contrast, a marked correlation for catchments draining basins of pure silicate lithology, most having low $[\mathrm{Mg}]^{*} /[\mathrm{K}]^{*}$ ratios between 1 and 0.2. Similar ratios have been obtained on Western Himalayan streams draining gneissic basins (Blum et al, 1998). Dissolved $\mathrm{Mg} / \mathrm{K}$ vary during silicate weathering because (1) $\mathrm{K}$ can be released by weathering of feldspars and muscovite which do not release $\mathrm{Mg}$ and (2) $\mathrm{Mg}$ and $\mathrm{K}$ are fractionated during secondary mineral formation in different directions depending on micas alteration reactions and alteration conditions (e.g. Mc Bride, 1994). Therefore we will examine silicate weathering budget with $\mathrm{Mg} / \mathrm{K}=0.5 \pm 0.25$ which corresponds to most of the measured ratios in silicate catchments. Equation 8 can then be expressed as:

$$
\left.[\mathrm{Mg}]^{*}=\mathrm{Mg}_{\text {carbonate }}+\mathrm{K}_{\text {silicate }} \times 0.5 \pm 0.25 \text { (in } \mu \mathrm{mol} / \mathrm{l}\right)
$$

While there is a large uncertainty to this ratio, it does not strongly affect the budget of silicate to carbonate weathering. This budget can now be calculated for main rivers because $\mathrm{K}_{\text {silicate }}$ is always low compared to $\mathrm{Ca}_{\text {carbonate }}$ and $\mathrm{Mg}_{\text {carbonate }}$.

The silicate to carbonate budget can then be expressed by the ratio of dissolved cations from silicates over the sum of dissolved cations from silicates plus carbonates. This can be expressed as ratio of equivalent cationic charge by combining equations 3,4 , 6,9 and 10 :

$\mathrm{X}_{\text {sil }}=\left(1.4 \times\left(\mathrm{Na}^{*}-\mathrm{Cl}^{*}\right)+2 \times \mathrm{K}^{*}\right) /\left(\mathrm{Na}^{*}+\mathrm{K}^{*}+2 \times \mathrm{Mg}^{*}+2 \times \mathrm{Ca}^{*}\right)$ 
Table 1 - Chemical data from the Kali Gandaki and tributaries

\begin{tabular}{|c|c|c|c|c|c|c|c|c|c|c|c|c|c|c|c|c|c|c|}
\hline Sample & River & $\overline{\text { Loc }}$ & Date & $\begin{array}{c}\text { Altituc } \\
\mathrm{m}\end{array}$ & $\begin{array}{c}\text { Temp } \\
{ }^{\circ} \mathrm{C}\end{array}$ & $\mathrm{pH}$ & $\begin{array}{l}\text { TDS } \\
\mathrm{mg} / \mathrm{l}\end{array}$ & ${ }_{\%}^{13} \mathrm{C}$ & $\overline{\mathrm{COO}_{3}}$ & $\mathrm{~F}^{-}$ & $\mathrm{Cl}^{-}$ & $\mathrm{SO}$ & $\mu \mathrm{r}$ & $\mathrm{Ia}^{+}$ & & $\mathrm{Mg}^{2+}$ & $\mathrm{Ca}^{2+}$ & $\mathrm{Si}$ \\
\hline$\overline{\mathrm{LO}} 25$ & Nang & 81 & May & 3695 & & & 161 & -6.7 & (2) & 2 & 11 & 89 & 0.3 & 77 & 21 & 109 & 839 & 170 \\
\hline & Kali & & & 50 & 5 & & 316 & & & & & 111 & bdl & 1254 & 106 & & & 250 \\
\hline 133 & & & & & 9.6 & 7 & 218 & & 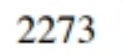 & & & 97 & & 455 & & & 82 & $18 \mathrm{C}$ \\
\hline 63 & ig & 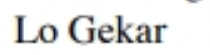 & & 20 & 4.5 & & 212 & & & & 17 & 402 & & 15 & 5 & & & $12^{7}$ \\
\hline $\mathrm{O} 23$ & $\mathrm{~T}$ & sar & & 3400 & & & 394 & -1.4 & 127 & & 38 & 371 & bdl & 697 & 8 & 7 & 759 & 270 \\
\hline 15 & & & & 385 & 6.3 & & 214 & & & & 34 & 300 & 0.3 & 134 & 7 & & 35 & 91 \\
\hline 96 & & & & 2900 & 10 & & 30 & & & & 740 & 687 & 15 & 4202 & 390 & & 25 & 68 \\
\hline 1 & & & & 800 & 14 & & 358 & & & & 0 & 62 & bdl & 37 & & & & 78 \\
\hline AG 21 & & & & 2790 & 3.8 & 8.5 & 426 & +0.4 & 32 & & 87 & 1096 & 14 & 912 & & & 28 & 93 \\
\hline 147 & & & & 2675 & 8.4 & 8.4 & 400 & .3 & 00 & 1 & 880 & 1081 & bdl & 1027 & 10 & & 78 & 83 \\
\hline 99 & & & & 2650 & & & 293 & & 527 & & 9 & 722 & 12 & 70 & & & 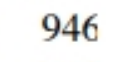 & 4 \\
\hline 3 & & & & 2635 & & & 183 & & & & 13 & 58 & bdl & 20 & & & 84 & 27 \\
\hline 01 & & & & 530 & 10 & & 348 & 1.4 & & & 622 & 019 & bdl & 78 & & & 1208 & nd \\
\hline & & & & 2626 & 6.3 & 9.3 & 418 & +0.3 & 2761 & & & 21 & 12 & 26 & & & 39 & 92 \\
\hline & & & & 0 & 2.0 & 8.8 & 41 & & & & 663 & 1171 & 1 & & & & & 92 \\
\hline & & & & 00 & 11 & 9.4 & 382 & -1.0 & 46 & & 465 & 02 & 5.3 & 73 & & & 89 & 78 \\
\hline & & & & 50 & 9 & 8.5 & 361 & -1 & 24 & & & 06 & 12 & 00 & & & 71 & 99 \\
\hline 41 & & & & & 8.9 & 8.5 & 165 & -3.3 & 1000 & & & 210 & 2. & 85 & & & 52 & 85 \\
\hline NH 10 & $\mathrm{~K}$ & & & 30 & 9.4 & 8.6 & 362 & -2.2 & & 1 & 6 & 826 & bdl & 759 & & & 1309 & 109 \\
\hline NAG 43 & Kali & & & 180 & 8.7 & & 314 & -3.0 & 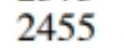 & & 361 & 34 & dl & 23 & & & 214 & 92 \\
\hline NH 31 & Mayo & Tat & & 905 & 11 & 8.3 & 256 & -7.1 & $2251^{\S}$ & & 84 & 387 & dl & 85 & & & 04 & 94 \\
\hline NH 8 & Kali & & & & 12 & 8.6 & 290 & -9 & & & 34 & 570 & bdl & 495 & & & 1072 & 103 \\
\hline NAG 45 & Kali & & & 740 & 13 & 8.6 & 231 & -4 & 2004 & & 188 & 433 & 6.8 & 254 & & & 921 & 101 \\
\hline & & & & 705 & 22 & 8.8 & 269 & -10.1 & $3221^{8}$ & & 44 & 57 & bdl & 69 & & & 372 & 100 \\
\hline $\mathrm{O} 310$ & 1 & & & 460 & 22 & & 186 & -8.9 & 1911 & & 3 & 212 & 0.3 & 113 & 50 & & 762 & 75 \\
\hline & & & & 46 & 17 & 8.8 & 26 & -6 & & 7 & 202 & 351 & bdl & 269 & 62 & 0 & 948 & 108 \\
\hline & & & & 460 & 18 & 84 & 206 & -9.0 & 2095 & & & 262 & bdl & 150 & & & 774 & 59 \\
\hline LO 306 & Kali & $\mathrm{N}$ & Jun.9.93 & 305 & 26 & & 162 & -7.8 & 1651 & 12 & 56 & 191 & 3.7 & 101 & 50 & 338 & 635 & 78 \\
\hline
\end{tabular}

$\S$ : alkalinity field titration. bdl: below the detection limit. nd: not determined 
Table 2 - Chemical data from the Trisuli river and tributaries

\begin{tabular}{|c|c|c|c|c|c|c|c|c|c|c|c|c|c|c|c|c|c|c|}
\hline$\overline{\text { Sample }}$ & River & Area & $\overline{\text { Date }}$ & Altitude & $\begin{array}{c}\text { Temp } \\
{ }^{\circ} \mathrm{C}\end{array}$ & $\mathrm{pH}$ & $\begin{array}{c}\mathrm{TDS} \\
\mathrm{mg} / \mathrm{l}\end{array}$ & $\begin{array}{c}\delta_{\% 0}^{13} \mathrm{C} \\
\sigma_{0}\end{array}$ & $\mathrm{HCO}_{3}-$ & $\mathrm{F}^{-}$ & $\mathrm{Cl}^{-}$ & $\mathrm{SO}_{4}{ }^{2-}$ & $\begin{array}{r}\mathrm{NO}_{3}^{-} \\
\mu \mathrm{mc}\end{array}$ & $\begin{array}{l}\mathrm{Na}^{+} \\
\mathrm{l} / \mathrm{l}\end{array}$ & $\mathrm{K}^{+}$ & $\mathrm{Mg}^{2+}$ & $\mathrm{Ca}^{2+}$ & $\overline{\mathrm{Si}}$ \\
\hline$\overline{L O ~ 237}$ & Lari & Lari valley & Jun.5.93 & 4245 & & & 40 & -9.4 & 428 & 2.6 & 4 & 37 & 12 & 5 & 14 & 102 & 149 & $\overline{17}$ \\
\hline LO 238 & Mailung & Paigutang & Jun.5.93 & 4020 & & & 18 & -8.6 & 155 & 1.5 & 3 & 22 & 22 & 17 & 16 & 32 & 60 & 19 \\
\hline LO 257 & Langtang & Syabru Bensi & Jun.6.93 & 1480 & & & 33 & -2.9 & 297 & 10 & 7 & 45 & 0.3 & 51 & 25 & 19 & 141 & 50 \\
\hline NH 100 & Langtang & Syabru Bensi & Apr.14.95 & 1455 & 11 & 7.8 & 50 & -4.8 & 432 & 13 & 14 & 82 & bdl & 110 & 21 & 42 & 205 & 114 \\
\hline NH 102 & Bhote Kosi & Syabru Bensi & Apr.14.95 & 1440 & 12 & 7.9 & 128 & -2.5 & 1174 & 8.9 & 58 & 203 & bdl & 175 & 32 & 209 & 514 & 113 \\
\hline LO 256 & Trisuli & Syabru Bensi & Jun.6.93 & 1430 & 13 & & 79 & -2.0 & 784 & 11 & 23 & 87 & 13 & 80 & 29 & 88 & 355 & 60 \\
\hline LO 258 & Trisuli & Betrawati & Jun.6.93 & 750 & 18 & & 73 & -4.9 & 739 & 11 & 18 & 75 & 6.0 & 84 & 28 & 76 & 327 & 64 \\
\hline TRI 19/6 & Trisuli & Betrawati & Jun.19.93 & 750 & & & 63 & -7.2 & 644 & 6.8 & 16 & 56 & 8.2 & 56 & 24 & 56 & 296 & 51 \\
\hline TRI 6/7 & Trisuli & Betrawati & Jul.6.93 & 750 & & & 71 & -10.4 & 760 & 6.3 & 17 & 42 & bdl & 57 & 51 & 51 & 328 & 80 \\
\hline TRI $15 / 7$ & Trisuli & Betrawati & Jul.15.93 & 750 & & & 81 & -8.6 & 897 & 6.8 & 14 & 41 & bdl & 44 & 39 & 49 & 409 & 57 \\
\hline TRI 1/8 & Trisuli & Betrawati & Aug.1.93 & 750 & & & 73 & -10.0 & 784 & 5.8 & 15 & 42 & bdl & 54 & 51 & 51 & 341 & 82 \\
\hline TRI $15 / 8$ & Trisuli & Betrawati & Aug.15.93 & 750 & & & 70 & -9.7 & 737 & 5.3 & 19 & 46 & bdl & 67 & 39 & 49 & 324 & 75 \\
\hline TRI $1 / 9$ & Trisuli & Betrawati & Sep.1.93 & 750 & & & 68 & -9.0 & 694 & 5.3 & 43 & 54 & bdl & 93 & 48 & 77 & 278 & 73 \\
\hline TRI $15 / 9$ & Trisuli & Betrawati & Sep.15.93 & 750 & & & 60 & -9.2 & 610 & 5.3 & 17 & 55 & bdl & 71 & 29 & 65 & 255 & 94 \\
\hline TRI $1 / 10$ & Trisuli & Betrawati & Oct.1.93 & 750 & & & 64 & -10.4 & 642 & 5.8 & 26 & 57 & 2.3 & 94 & 35 & 73 & 257 & 107 \\
\hline TRI $15 / 10$ & Trisuli & Betrawati & Oct.15.93 & 750 & & & 79 & -5 . & 766 & 8.4 & 35 & 85 & 6.3 & 124 & 33 & 94 & 319 & 114 \\
\hline TRI 1/11 & Trisuli & Betrawati & Nov.1.93 & 750 & & & 80 & -6.7 & 779 & 7.9 & 33 & 84 & bdl & 129 & 37 & 93 & 318 & 116 \\
\hline TRI $1 / 12$ & Trisuli & Betrawati & Dec.1.93 & 750 & & & 95 & -8 . & 911 & 9.5 & 49 & 111 & 1.5 & 170 & 38 & 117 & 376 & 127 \\
\hline TRI 4/4 & Trisuli & Betrawati & Apr.4.94 & 750 & & & 107 & & 1027 & 9.5 & 49 & 133 & 1.9 & 200 & 43 & 136 & 418 & 125 \\
\hline KN 76 & Tadi & Source & Mar.21.94 & 3665 & & & 11 & & 80 & 1.6 & 4.1 & 21 & 17 & 26 & 9 & 8 & 46 & 68 \\
\hline $\mathrm{KN} 82$ & Hundi & Shisipur & Mar.21.94 & 2130 & & & 12 & & 83 & 2.3 & 4.5 & 21 & 19 & 50 & 8 & 10 & 35 & 103 \\
\hline KN 84 & Tadi & Ghyangphedi & Mar.21.94 & 2050 & & & 32 & & 321 & 4.4 & 5.9 & 32 & 13 & 54 & 17 & 16 & 153 & 110 \\
\hline KN 93 & Tadi & Satbise & Mar.23.94 & 945 & & & 27 & & 262 & 3.9 & 6.7 & 32 & 10 & 99 & 20 & 20 & 94 & 178 \\
\hline KN 95 & Chake & Samundratar & Mar.23.94 & 935 & & & 30 & & 331 & 3.7 & 11 & 16 & 0.2 & 175 & 26 & 22 & 67 & 263 \\
\hline $\mathrm{KN} 102$ & Likhu & Bhadrutar & Mar.24.94 & 750 & & & 55 & & 598 & 7.3 & 23 & 30 & 0.2 & 230 & 45 & 47 & 159 & 310 \\
\hline LO 316 & Trisuli & Adamghat & Jun.10.93 & 465 & 21 & & 84 & -8 & 889 & 8.9 & 19 & 62 & 0.3 & 94 & 32 & 84 & 370 & 93 \\
\hline LO 304 & Trisuli & Gumaune & Jun.9.93 & 320 & 21 & & 115 & -5.7 & 1121 & 11 & 63 & 140 & 0.3 & 119 & 35 & 152 & 505 & 84 \\
\hline
\end{tabular}


Table 3 - Chemical data for other rivers of the Narayani basin and Bothe Kosi at Kodari.

\begin{tabular}{|c|c|c|c|c|c|c|c|c|c|c|c|c|c|c|c|c|c|c|}
\hline Sample & River & Location & $\overline{\text { Date }}$ & $\begin{array}{c}\text { Altitude } \\
\mathrm{m}\end{array}$ & $\begin{array}{c}\text { Temp } \\
{ }^{\circ} \mathrm{C}\end{array}$ & $\mathrm{pH}$ & $\begin{array}{l}\mathrm{TDS} \\
\mathrm{mg} / \mathrm{l}\end{array}$ & $\delta_{\% 0}^{13} \mathrm{C}$ & $\mathrm{HCO}_{3}^{-}$ & $\mathrm{F}^{-}$ & $\mathrm{Cl}^{-}$ & $\mathrm{SO}_{4}{ }^{2-}$ & $\begin{array}{l}\mathrm{NO}_{3}^{-} \\
\mu \mathrm{mo}\end{array}$ & $\begin{array}{l}\mathrm{Na}^{+} \\
1 / 1\end{array}$ & $\overline{\mathrm{K}^{+}}$ & $\mathrm{Mg}^{2+}$ & $\mathrm{Ca}^{2+}$ & $\overline{\mathrm{Si}}$ \\
\hline \multicolumn{19}{|c|}{ BHURI GANDAKI } \\
\hline MO 107 & Mati & Arughat & May.12.97 & & 27 & & 78 & -11.6 & 887 & & 19 & 28 & 1.1 & 255 & 59 & 76 & 248 & \\
\hline MO 125 & Sueli & & May.14.97 & & 30 & & 49 & -12.7 & 580 & & 21 & 4 & bdl & 194 & 23 & 58 & 138 & \\
\hline $\begin{array}{l}\text { LO } 300 \\
\text { MARSYA }\end{array}$ & $\begin{array}{l}\text { Bhuri Gandaki } \\
\text { ANDI }\end{array}$ & \multicolumn{9}{|c|}{ MARSYANDI } & 24 & 174 & 13 & 75 & 29 & 176 & 559 & 59 \\
\hline NAG 24 & Marsyandi & source & Nov.28.95 & 5050 & 0 & & 606 & -1.3 & 2937 & 2.1 & 4.1 & 2852 & bdl & 48 & 23 & 1353 & 2925 & 30 \\
\hline HF 131 & Miyardi & & May.7.93 & 3920 & & & 18 & & 206 & 0.6 & 3.7 & 5 & bdl & 7 & 12 & 7 & 93 & 12 \\
\hline MO 58 & Chepe & & May.7.97 & 3100 & & & 17 & -8.4 & 168 & & 1.6 & 17 & 8.6 & 30 & 15 & 6 & 77 & \\
\hline MO 79 & Khota & & May.9.97 & 1700 & 15 & & 42 & -10.9 & 449 & & 3.3 & 31 & bdl & 69 & 68 & 34 & 154 & \\
\hline MO 28 & Dordi & Darimbote & May.4.97 & 1450 & 10 & & 48 & -5.9 & 414 & & 5.1 & 101 & 5.7 & 53 & 37 & 29 & 239 & \\
\hline MO 100 & Marsel & & May.11.97 & 590 & 23 & & 55 & -11.3 & 633 & & 17 & 17 & bdl & 235 & 49 & 60 & 140 & \\
\hline LO 314 & Marsyandi & Markichok & Jun.10.93 & 435 & 20 & & 127 & -6.0 & 1173 & 11 & 140 & 170 & 0.3 & 157 & 45 & 165 & 561 & 80 \\
\hline \multicolumn{19}{|c|}{ SETI KHOLA } \\
\hline HF 126 & Chhar & Rambong & May.5.93 & 3785 & & & 6.4 & & 73 & 0.5 & 3.2 & 1 & bdl & 5 & 8 & 7 & 26 & 2 \\
\hline HF 111 & Chhar & Rambong & May.4.93 & 3680 & & & 8.3 & & 72 & 0.5 & 3.3 & 5 & bdl & 18 & 11 & 8 & 20 & 48 \\
\hline HF 103 & Madi & Siklis & May.2.93 & 1435 & & & 103 & -7.5 & 1058 & 10 & 41 & 87 & 31 & 60 & 31 & 30 & 580 & \\
\hline HF 141 & Madi & Khilang & May.10.93 & 1040 & & & 102 & & 1086 & 3.7 & 45 & 77 & 1.3 & 81 & 43 & 40 & 542 & 31 \\
\hline NH 40 & Sardi & Khadarjung & Mar.16.95 & 1185 & 17 & 8.5 & 133 & -8.3 & 1341 & 4.7 & 10 & 153 & bdl & 58 & 82 & 205 & 555 & 169 \\
\hline NH 39 & Seti & Khadarjung & Mar.16.95 & 1180 & 9.9 & 7.9 & 208 & -3.4 & $1730 \S$ & 7.4 & 190 & 430 & bdl & 228 & 54 & 329 & 918 & 83 \\
\hline NAG 3 & Bijapur & Kundahar & Nov.11.95 & 870 & 21 & 8.1 & 149 & -10.3 & 1670 & 3.7 & 68 & 64 & 3.7 & 87 & 51 & 290 & 578 & 136 \\
\hline LO 312 & Seti & Kotre Bazar & Jun.10.93 & 585 & 26 & & 179 & -6.7 & 1893 & 9.5 & 42 & 171 & 0.3 & 87 & 57 & 332 & 738 & 107 \\
\hline LO 302 & Seti & Sarang Ghat & Jun.9.93 & 325 & 26 & & 162 & -7.4 & 1688 & 8.4 & 33 & 174 & 0.3 & 102 & 51 & 322 & 636 & 120 \\
\hline \multicolumn{19}{|c|}{ NARAYANI } \\
\hline LO 308 & Narayani & Nayaran Ghat & Jun.9.93 & 225 & 26 & & 145 & -8.0 & 1458 & 10 & 60 & 169 & 0.3 & 114 & 51 & 244 & 602 & 96 \\
\hline NH 1 & Narayani & Nayaran Ghat & Mar.10.95 & 225 & 20 & 8.5 & 202 & -5.6 & $2038 \S$ & 10 & 148 & 245 & bdl & 230 & 50 & 439 & 739 & 143 \\
\hline NAG 49 & Narayani & Nayaran Ghat & Dec.11.95 & 225 & 19 & 8.4 & 207 & -7.1 & 2143 & 6.3 & 88 & 214 & bdl & 185 & 68 & 429 & 777 & 159 \\
\hline NH 20 & Bothe Kosi & Kodari & Mar.17.95 & & 6.5 & 8.2 & 107 & -2.0 & $1169 \S$ & 8.4 & 20 & 120 & bdI & 163 & 14 & 112 & 468 & $\overline{124}$ \\
\hline
\end{tabular}

§: alkalinity by field titration. 
Table 4 - Chemical data for river from Karnali basin and Siwaliks.

\begin{tabular}{|c|c|c|c|c|c|c|c|c|c|c|c|c|c|c|c|c|c|c|}
\hline Sample & River & Location & Date & Altitude & $\begin{array}{c}\text { Tem } \\
{ }^{\circ} \mathrm{C}\end{array}$ & $\overline{\mathrm{pH}}$ & $\begin{array}{l}\text { TDS } \\
\mathrm{mg} / \mathrm{l}\end{array}$ & $\delta_{\% o}^{13} \mathrm{C}$ & $\mathrm{HCO}_{3}^{-}$ & $\mathrm{F}^{-}$ & $\mathrm{Cl}^{-}$ & $\mathrm{SO}_{4}^{2}$ & $\begin{array}{l}\mathrm{NO}_{3}^{-} \\
\mu \mathrm{mo}\end{array}$ & $\begin{array}{l}\mathrm{Na}^{+} \\
\mathrm{b} / \mathrm{l}\end{array}$ & $\mathrm{K}^{+}$ & $\mathrm{Mg}^{2+}$ & $\mathrm{Ca}^{2+}$ & $\mathrm{Si}$ \\
\hline$\overline{\mathrm{NH}} 80$ & Thuli & Dunai & Mar.21.9 & 2030 & 8.3 & 8.5 & 234 & -4.0 & $2089 \S$ & 3.7 & 16 & 526 & bdl & 88 & 29 & 553 & 956 & 67 \\
\hline NAG 47 & Thuli & Dunai & Nov.25.9 & 2030 & & & 229 & -8.3 & 1852 & 2.6 & 222 & 512 & 17 & 147 & 64 & 498 & 954 & 57 \\
\hline NH 71 & Tilla Nadi & Tatopani & Mar.21.9 & 2130 & 14 & 8.8 & 125 & -10.5 & $1495 \S$ & 7.7 & 31 & 77 & bdl & 58 & 82 & 205 & 555 & \\
\hline NAG 14 & Bheri & Sampujighat & Nov.18.9 & 370 & 17 & 8.3 & 195 & -7.9 & 2111 & 3.7 & 19 & 183 & 7.3 & 90 & 40 & 442 & 746 & 95 \\
\hline NAG & Bheri & Sampujighat & Jun.95 & 370 & & & 198 & & 2176 & 2.4 & 32 & 156 & bdl & 84 & 70 & 354 & 830 & 84 \\
\hline NĂG & Bheri & Sampujighat & Aug.95 & 370 & & & 174 & & 1985 & 1.8 & 18 & 96 & 0.6 & 40 & 53 & 304 & 748 & 87 \\
\hline NÄG & Bheri & Sampujighat & Sep.95 & 370 & & & 174 & & 1920 & 2.6 & 14 & 149 & bdl & 56 & 38 & 393 & 678 & 106 \\
\hline $94-16$ & Bheri & Ghatgaun & Mar.27.9 & & & & 222 & & 2422 & 3.7 & 31 & 203 & 0.3 & 160 & 52 & 499 & 826 & 101 \\
\hline $94-15$ & Karnali & Ghatgaun & Mar.25.9 & & & & 161 & & 1694 & 13 & 47 & 149 & 0.3 & 151 & 49 & 283 & 644 & 108 \\
\hline NAG 11 & Karnali & Kotillaghat & $\underset{\tau}{\text { Nov.17.9 }}$ & 100 & 20 & 8.6 & 229 & -8.0 & 1595 & 7.9 & 29 & 131 & 6.6 & 198 & 46 & 432 & 896 & 146 \\
\hline NAG 19 & Rapti & Darbang & Nov.21.9 & 290 & 19 & 8.6 & 229 & -10.5 & 2590 & 7.4 & 26 & 141 & bdl & 144 & 62 & 456 & 893 & 155 \\
\hline NAG 10 & Rapti & Bhabaniyapur & $\underset{\tau}{\text { Nov.16.9 }}$ & 140 & 22 & 8.6 & 274 & -9.3 & 3156 & 5.8 & 27 & 131 & bdl & 149 & 79 & 475 & 1136 & 151 \\
\hline 94-05 & Sarda & Luham & Mar.8.94 & 1400 & & & 200 & & 2375 & 4.2 & 80 & 40 & 0.3 & 133 & 18 & 425 & 768 & 124 \\
\hline NAG 15 & Sarda & Luham & Nov.16.9 & 1400 & & & 140 & -10.1 & 1571 & 3.7 & 52 & 61 & bdl & 130 & 28 & 212 & 584 & 148 \\
\hline \multicolumn{19}{|c|}{ SIWALIKS } \\
\hline 94-01 & Chor & Upper part & Mar.2.94 & & & & 670 & & 7139 & 16 & 71 & 628 & bdl & 3488 & 124 & 1059 & 1373 & 175 \\
\hline $94-02$ & Suraî & Upper part & Mar.4.94 & & & & 599 & & 6574 & 22 & 70 & 415 & 0.3 & 3729 & 108 & 1020 & 807 & 268 \\
\hline NH 3 & Suraï & Tatopani & Mar.11.9 & & 18 & 8.5 & 631 & -8.6 & $6764 \S$ & 14 & 46 & 217 & bdl & 3277 & 286 & 1148 & 974 & 320 \\
\hline $94-03$ & Rangsing & Charange & Mar.5.94 & & & & 331 & & 3920 & 6.8 & 34 & 104 & 0.3 & 473 & 53 & 556 & 1264 & 132 \\
\hline $94-13$ & Gadel & Palaite & Mar.23.9 & & & & 325 & & 3988 & 5.8 & 52 & 6 & 0.3 & 197 & 46 & 581 & 1326 & 199 \\
\hline $94-14$ & Basunti & Bashanti & Mar.24.9 & & & & 270 & & 3292 & 6.8 & 33 & 14 & 3.5 & 138 & 43 & 360 & 1231 & 113 \\
\hline $94-17$ & Kachali & & Mar.29.9 & & & & 403 & & 4699 & 8.4 & 22 & 148 & 1.8 & 1768 & 84 & 794 & 789 & 203 \\
\hline $94-18$ & Banka & & Mar.29.9 & & & & 477 & & 5515 & 6.3 & 31 & 204 & 0.3 & 2167 & 95 & 833 & 1010 & 165 \\
\hline
\end{tabular}

$\S$ : alkalinity by field titration; * : sample filtred in the laboratory and non acidified. 
Table 5 - Chemical data for rivers in Bangladesh

\begin{tabular}{|c|c|c|c|c|c|c|c|c|c|c|c|c|c|c|c|c|c|}
\hline ample & River & Loc: & Date & $\begin{array}{c}\text { Temp } \\
{ }^{\circ} \mathrm{C}\end{array}$ & & $\begin{array}{l}\text { TDS } \\
\mathrm{mg} / \mathrm{l}\end{array}$ & $\delta_{\% o}^{13 C}$ & $\mathrm{HCO}_{3}^{-}$ & $\mathrm{F}^{-}$ & $\mathrm{Cl}^{-}$ & $\mathrm{SO}_{4}{ }^{2-}$ & $\begin{array}{r}\mathrm{NO}_{3} \\
\mu 1\end{array}$ & $\mathrm{Na}^{+}$ & $\overline{\mathrm{K}^{+}}$ & $\mathrm{g}^{2+}$ & $\mathrm{Ca}^{2+}$ & S1 \\
\hline$\overline{\mathrm{GP}} 12$ & Tista & $\overline{\text { Kat }}$ & $\overline{\mathrm{Au}}$ & 28 & 7.2 & $\overline{41}$ & -11.9 & $350 \S$ & 7.1 & 21 & $\overline{42}$ & $\overline{b d}$ & 51 & 37 & $\overline{45}$ & $\overline{153}$ & \\
\hline 72 & Tista & & & 24 & 8.1 & 79 & 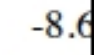 & 817 & 13 & 34 & 78 & b & & 41 & 1 & 58 & \\
\hline GP 4 & Gar & & & 31 & 7.6 & 125 & -10.1 & $1421 \S$ & 10 & די & 76 & & & 69 & 201 & 466 & 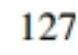 \\
\hline 65 & Gan & & & 24 & 8.5 & 374 & -8.2 & 12 & 10 & 234 & 64 & & 9 & 110 & 12 & 1418 & \\
\hline $\mathrm{Gl}$ & $\mathrm{Bra}$ & & & 2 & 7.6 & 105 & .1 & 11 & 4.3 & 5 & 5 & b & & 2 & 8 & 3 & 15 \\
\hline GP & Bral & & & 2. & 8.5 & 145 & -8.3 & 1. & 8 & 53 & 9 & 1.6 & & 75 & 4 & 90 & \\
\hline GP 51 & B & A & 1 & 22 & 8.4 & 154 & -9.2 & 16 & 8 & 58 & 154 & 1 & 28 & 26 & 233 & 613 & He \\
\hline $3 \mathrm{GP} 39$ & Upper $\mathrm{N}$ & Bhair & .96 & 30 & 7.2 & 38 & - & $395 \S$ & 3.5 & 30 & 21 & 2. & 84 & 18 & 68 & 108 & 129 \\
\hline $3 \mathrm{GP} 0$ & Upper Meghna & Nangalband & Oct.20.94 & & & 47 & & 512 & 2.6 & 25 & 7 & 1.6 & 113 & 37 & 86 & 117 & 26 \\
\hline $3 G P 20$ & Lower Meghna & Bhola & Aug.10.96 & 30 & 8.1 & 127 & -9.0 & $1350 \S$ & 7.6 & 78 & 77 & 23 & 229 & 41 & 182 & 489 & 129 \\
\hline
\end{tabular}

$\S$ : alkalinity by field titration. 
Table 6 - Average chemical composition of river water in the G-B system

\begin{tabular}{|c|c|c|c|c|c|c|c|c|c|c|c|c|c|}
\hline Zone & $\begin{array}{l}\text { Catchment } \\
\text { Type }\end{array}$ & $\mathrm{n}$ & $\delta_{\% o}^{13} \mathrm{C}$ & $\mathrm{pH}$ & $\begin{array}{l}\mathrm{TDS} \\
\mathrm{mg} / \mathrm{l}\end{array}$ & $\mathrm{HCO}_{3}{ }^{-}$ & $\mathrm{Cl}^{-}$ & $\mathrm{SO}_{4}{ }^{2-}$ & $\begin{array}{r}\mathrm{Na}^{+} \\
\mu \mathrm{m}\end{array}$ & $\begin{array}{l}\mathrm{K}^{+} \\
\mathrm{ol} / \mathrm{l}\end{array}$ & $\mathrm{Mg}^{2+}$ & $\mathrm{Ca}^{2+}$ & $\overline{\mathrm{H}_{2} \mathrm{SiO}_{4}}$ \\
\hline$\overline{\text { North Flank }}$ & Composite & 6 & -3.1 & 8.5 & 270 & 2060 & $\overline{20}$ & $\overline{790}$ & 90 & 30 & 550 & 1220 & $\overline{80}$ \\
\hline Mustang & Graben & 11 & +0.2 & 8.7 & 410 & 2900 & 710 & 1080 & 1140 & 110 & 820 & 1420 & 130 \\
\hline South Flank & Composite & 25 & -8.4 & 8.3 & 160 & 1680 & 50 & 120 & 120 & 40 & 250 & 520 & 100 \\
\hline South Flank & Gneiss & 11 & -8.9 & 7.5 & 30 & 310 & 10 & 30 & 70 & 20 & 20 & 120 & 120 \\
\hline Ganges & & & -10.1 & 7.6 & 130 & 1420 & 90 & 80 & 180 & 70 & 200 & 470 & 130 \\
\hline Brahmaputra & & & -10.1 & 7.6 & 110 & 1110 & 20 & 60 & 100 & 50 & 170 & 390 & 160 \\
\hline
\end{tabular}

All data are rounded average and therefore may not satisfy the charge neutrality. 
Table 7 - Chemical composition of rain water in the Ganges-Brahmaputra basin

\begin{tabular}{|c|c|c|c|c|c|c|c|c|c|c|c|c|c|c|c|c|}
\hline Source & Location & Area & Date & Type & $\mathrm{n}$ & \multicolumn{2}{|c|}{$\begin{array}{l}\text { TDS } \mathrm{HCO}_{3}^{-} \\
\mathrm{mg} / \mathrm{l}\end{array}$} & $\mathrm{F}^{-}$ & $\mathrm{Cl}^{-}$ & $\mathrm{SO}_{4}{ }^{2-}$ & $\begin{array}{r}\mathrm{NO}_{3}^{-} \\
\mu \mathrm{mc}\end{array}$ & $\begin{array}{l}\mathrm{Na}^{+} \\
1 / 1\end{array}$ & $\mathrm{~K}^{+}$ & $\mathrm{Mg}^{2+}$ & $\mathrm{Ca}^{2+}$ & $\mathrm{Si}$ \\
\hline (1) & Tibet & Everest & Spring 1986 & snow & 120 & & & & 6.1 & 2.9 & 4.5 & 7.5 & & & $\overline{16}$ & $\overline{0.5}$ \\
\hline (1) & Nepal & Yala & $1970-81$ & snow & 55 & & & & 9.9 & 2.4 & 2.1 & 11 & & & & \\
\hline (2) & Nepal & Ngozumpa & $1989-90$ & snow & 30 & & & & 0.3 & 0.1 & 0.1 & 0.3 & & & 0.2 & \\
\hline (2) & Tibet & Xixabangma & $1990-91$ & snow & 31 & & & & 0.5 & 0.2 & 0.6 & 0.4 & & & 0.6 & \\
\hline (2) & Tibet & Qiang Yong & $1990-91$ & snow & 17 & & & & 0.5 & 0.2 & 0.6 & 0.4 & & & 0.6 & \\
\hline (3) & Nepal & Likhu & $1991-93$ & rain & 73 & & & & & 9.4 & 4.2 & 13 & 4.9 & 17 & 29 & \\
\hline (4) & Nepal & Kathmandu & $1995-96$ & rain & 11 & 9.3 & 91 & 1.3 & 8.7 & 6.2 & 5.3 & 15 & 7.9 & 3.0 & 44 & 4.2 \\
\hline & Himalaya & Weighted Av & erage & & & & $68 \S$ & & 7.4 & 4.7 & 3.9 & 10 & 2.2 & 6.1 & 22 & 0.8 \\
\hline (5) & India & Calcutta & 1967 & rain & 112 & & & & 41 & 35 & 4.6 & 41 & 8.4 & 15 & 48 & 62 \\
\hline (6) & India & Calcutta & 1975 & rain & 56 & & & & 28 & 7.8 & & 37 & 4.4 & 4.9 & 17 & \\
\hline (6) & India & Delhi & 1975 & rain & 56 & & & & 18 & 4.4 & & 30 & 5.9 & 3.7 & 29 & \\
\hline (6) & India & Gulmarg & 1975 & rain & 28 & & & & 8.7 & 3.5 & & 20 & 3.1 & 6.6 & 22 & \\
\hline (4) & Bangladesh & & $\begin{array}{c}\text { monsoon } \\
1996\end{array}$ & rain & 7 & 5.8 & 26 & 1.2 & 20 & 12 & 8.6 & 17 & 16 & 2.4 & 20 & 3.0 \\
\hline & Plain & Weighted Av & erage & & & & $55 \S$ & & 29 & 19 & 4.8 & 35 & 6.6 & 9.0 & 34 & \\
\hline
\end{tabular}

The very high concentration of $\mathrm{Cl}$ in Collins and Jenkins (1996) were excluded because the charge balance of these analyses imply no $\mathrm{HCO}_{3}{ }^{-}$in the rain and a deficit of cations. $\S$ : by charge balance. Sources : (1) : Wake et al. (1990); (2) : Wake et al. (1993); (3) : Collins and Jenkins (1996); (4) : this study ; (5) : Handa (1969); (6) : Sequeira and Kelkar (1978). 
Table 8 : Chemical denudation rate for main sampled rivers

\begin{tabular}{|c|c|c|c|c|c|c|}
\hline$\overline{\text { River }}$ & Location & Season & $\begin{array}{l}\text { Discharge } \\
10^{9} \mathrm{~m}^{3} / \mathrm{yr}\end{array}$ & $\begin{array}{l}\text { Surface } \\
10^{3} \mathrm{~km}^{2}\end{array}$ & $\begin{array}{l}\text { Silicate } \\
\mathrm{mm} / \mathrm{yr}\end{array}$ & $\begin{array}{l}\text { Carbonate } \\
\mathrm{mm} / \mathrm{yr}\end{array}$ \\
\hline Trisuli & Betrawati & Monsoon & 4.2 & 4.6 & $0.007 \pm 3$ & $0.033 \pm 15$ \\
\hline Trisuli & Betrawati & Other & 1.5 & 4.6 & $0.003 \pm 1$ & $0.009 \pm 3$ \\
\hline Trisuli & Betrawati & Yeard & 5.8 & 4.6 & 0.005 & 0.021 \\
\hline Bheri & Sampujigha & Monsoon & 10.3 & 12.3 & $0.011 \pm 2$ & $0.131 \pm 29$ \\
\hline Bheri & Sampujigha & Other & 3.4 & 12.3 & $0.002 \pm 1$ & $0.024 \pm 16$ \\
\hline Bheri & Sampujighat & Yeard & 13.7 & 12.3 & 0.005 & 0.060 \\
\hline Narayani & Narayangha & Yeard & 49.4 & 31.8 & 0.007 & 0.052 \\
\hline Tista & Kaunia & Yeard & 26.0 & 12.5 & 0.008 & 0.013 \\
\hline Brahmaputra & Chilmari & Yeard & 612 & 583 & 0.004 & 0.021 \\
\hline Brahmaputra & GEMS & Year & 612 & 583 & 0.005 & 0.018 \\
\hline Ganges & Rajshahi & Yeard & 459 & 1060 & 0.002 & 0.013 \\
\hline Ganges & GEMS & Year & 459 & 1060 & 0.003 & 0.011 \\
\hline
\end{tabular}

I : Annual chemical denudation rates correspond to monsoonal rate over 4 months and dry season rates are the ramaining months. In order to calculate the chemical denudation rate an average density of 2.7 and 2.4 for silicate and carbonate were applied. GEMS : average data from UNEP GEMS/WATER Program. 
Table 9 - Fluxes of dissolved element in the different zones of the Ganges and Brahmaputra basin

\begin{tabular}{|c|c|c|c|c|c|c|c|c|c|c|}
\hline \multirow{2}{*}{ Rivers } & Discharge & Surface & $\mathrm{Cl}^{-}$ & $\mathrm{Na}^{+}$ & $\mathrm{K}^{+}$ & $\mathrm{Mg}^{2+}$ & $\mathrm{Ca}^{2+}$ & $\mathrm{HCO}_{3}^{-}$ & $\mathrm{SO}_{4}^{2-}$ & $\overline{\mathrm{H}_{2} \mathrm{SiO}_{4}}$ \\
\hline & $10^{9} \mathrm{~m}^{3 /} / \mathrm{yr}$ & $10^{3} \mathrm{~km}^{2}$ & \multicolumn{8}{|c|}{$10^{9} \mathrm{~mol} / \mathrm{yr}$} \\
\hline Ganges & 459 & 1060 & 40 & 128 & 29 & $\overline{93}$ & 252 & 713 & 39 & 59 \\
\hline Indian Shield & 100 & 328 & 26.8 & 82.4 & 5.2 & 37.1 & 69.3 & 256 & 5.4 & 17.8 \\
\hline Himalaya ${ }^{\S}$ & 206 & 176 & 9.5 & 27.5 & 12.2 & 68.6 & 138 & 387 & 31.2 & 25.7 \\
\hline $\begin{array}{l}\text { Plain\# } \\
\pm\end{array}$ & 153 & 556 & $\begin{array}{c}3.8 \\
114 \%\end{array}$ & $\begin{array}{c}18 \\
74 \%\end{array}$ & $\begin{array}{c}12 \\
10 \%\end{array}$ & $\begin{array}{l}-13 \\
60 \%\end{array}$ & $\begin{array}{l}44.3 \\
34 \%\end{array}$ & $\begin{array}{l}70.5 \\
74 \%\end{array}$ & $\begin{array}{c}2.3 \\
83 \%\end{array}$ & $\begin{array}{l}15.4 \\
23 \%\end{array}$ \\
\hline Plain/Ganges & $33 \%$ & & $10 \pm 11 \%$ & $14 \pm 10 \%$ & $41 \pm 4 \%$ & $-14 \pm 9 \%$ & $18 \pm 6 \%$ & $10 \pm 7 \%$ & $6 \pm 5 \%$ & $26 \pm 6 \%$ \\
\hline Brahmaputra & 612 & 583 & 19 & 55 & 29 & 94 & 211 & 473 & 91 & 78 \\
\hline G-B & 1071 & 1643 & 59 & 183 & 59 & 187 & 462 & 1185 & 130 & 137 \\
\hline World rivers & 37400 & 148170 & 6120 & 8460 & 1240 & 5230 & 12500 & 31900 & 2060 & 6480 \\
\hline
\end{tabular}

I: The Indian Shield contribution is the sum of each documented southern tributaries of the Ganges.

$\S$ : The Himalaya are the sum of each main river that cross the MFT.

\# : The plain contributions are the missing fluxes between the mouth and Himalayan + Indian Shield contribution.

Relative uncertainties are the propagation of $5 \%$ and $15 \%$ uncertainties on the Himalayan and Indian Shield riverine

concentration respectively. Therefore only $\mathrm{K}, \mathrm{Ca}, \mathrm{Si}$ and at a lesser extent alkalinity are significative. 
Fig. 1

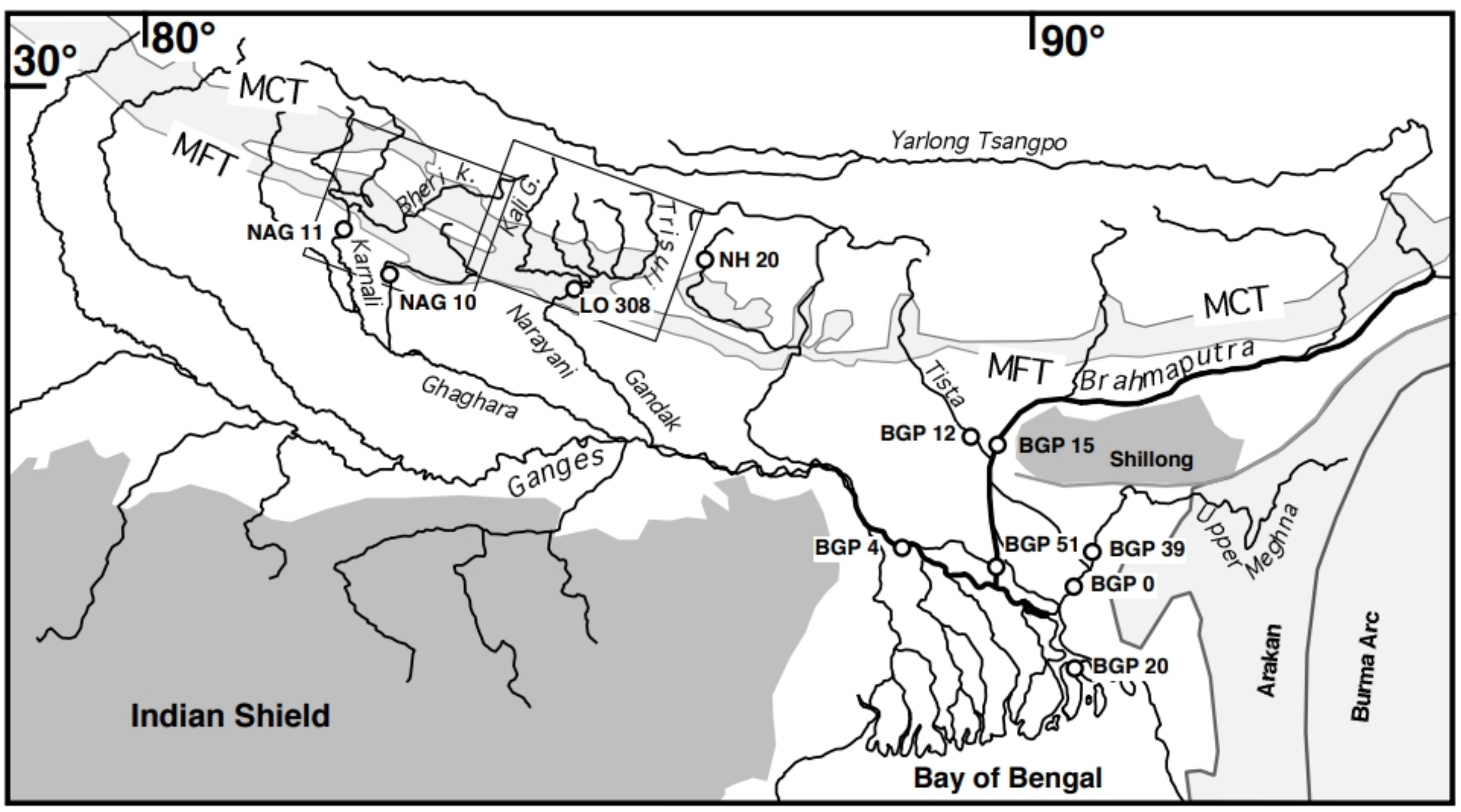




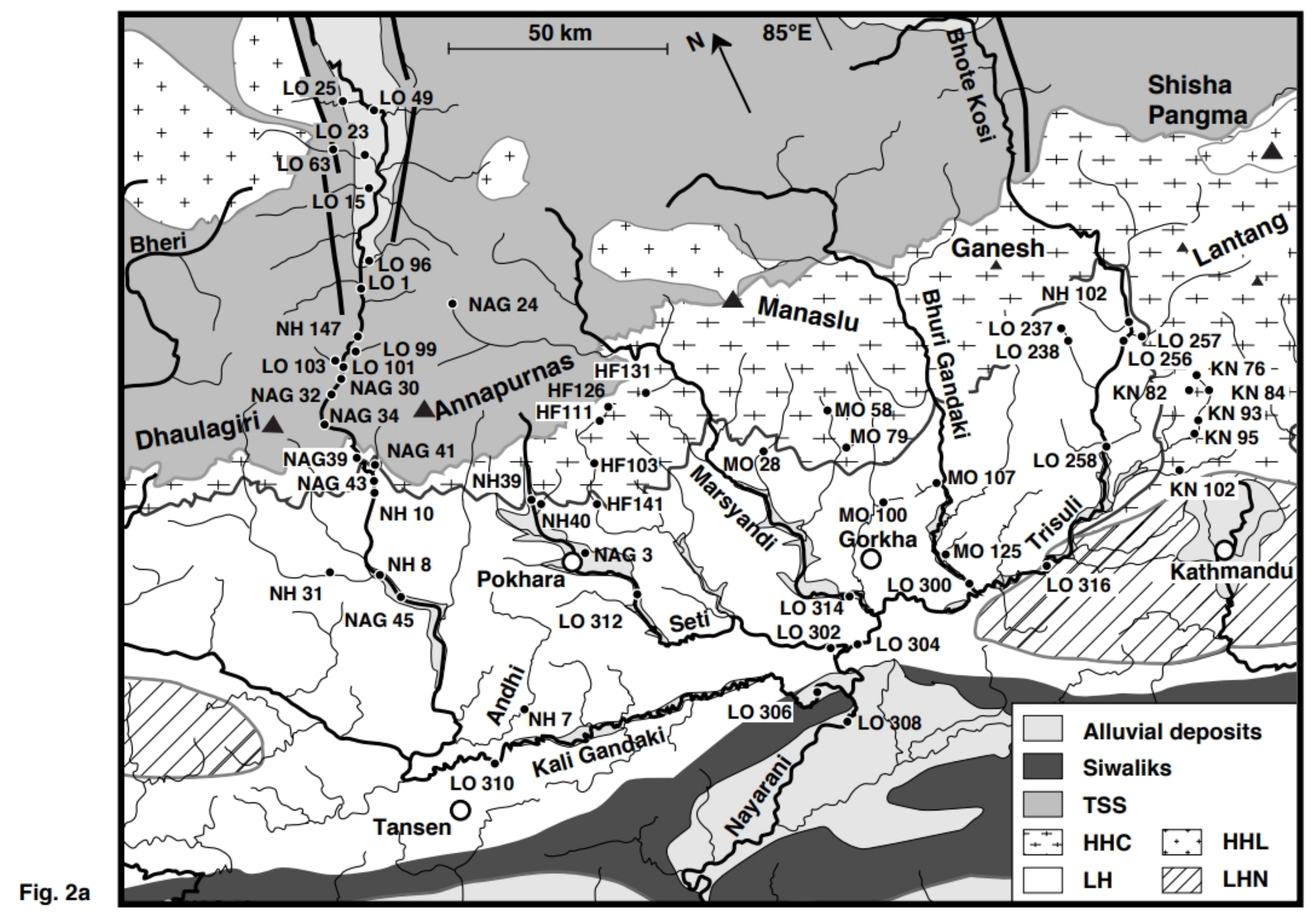




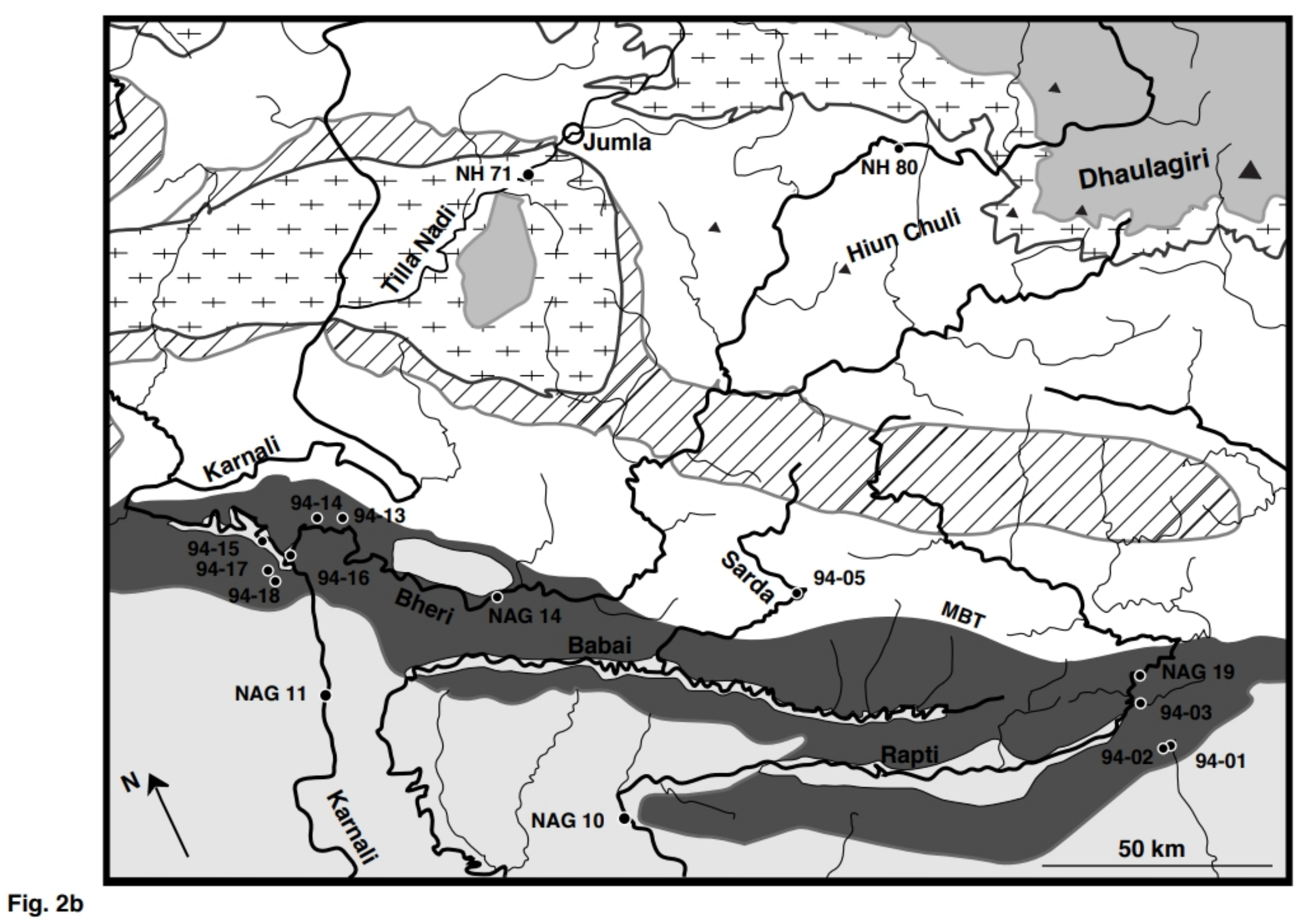


Fig. 3a

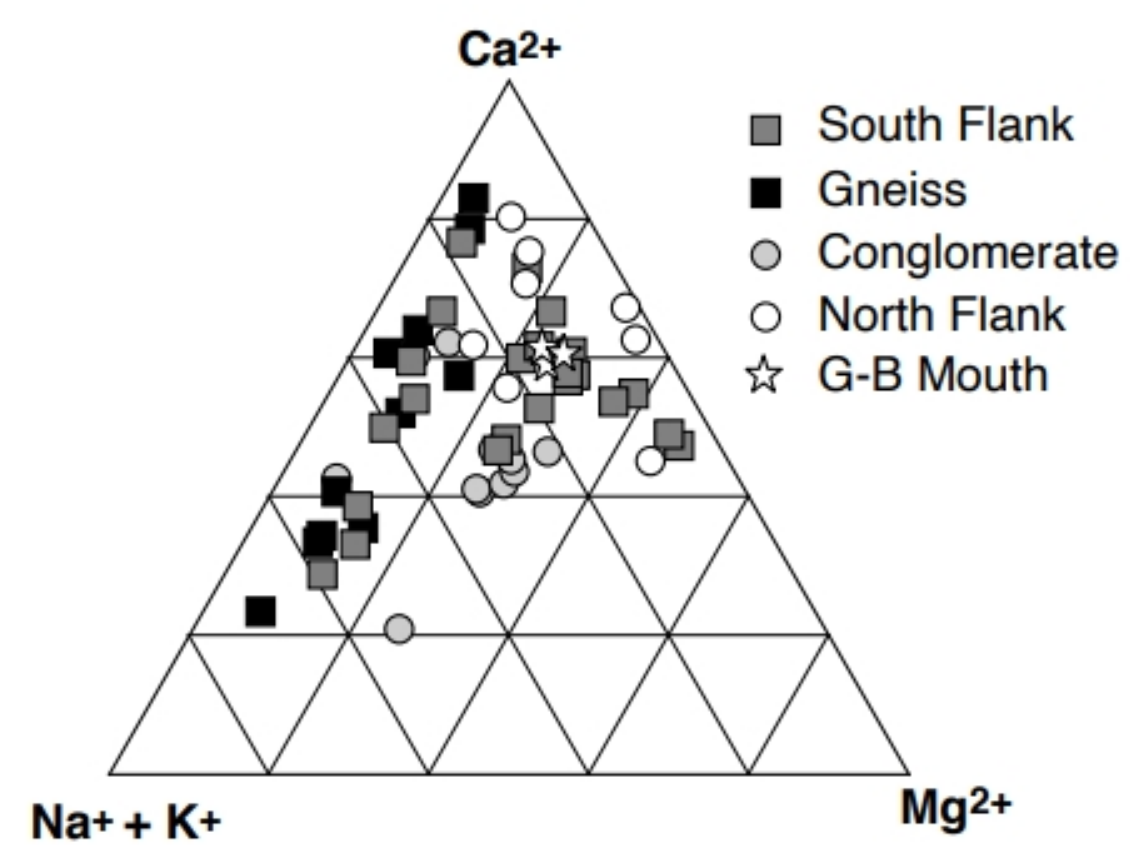

Fig. 3b

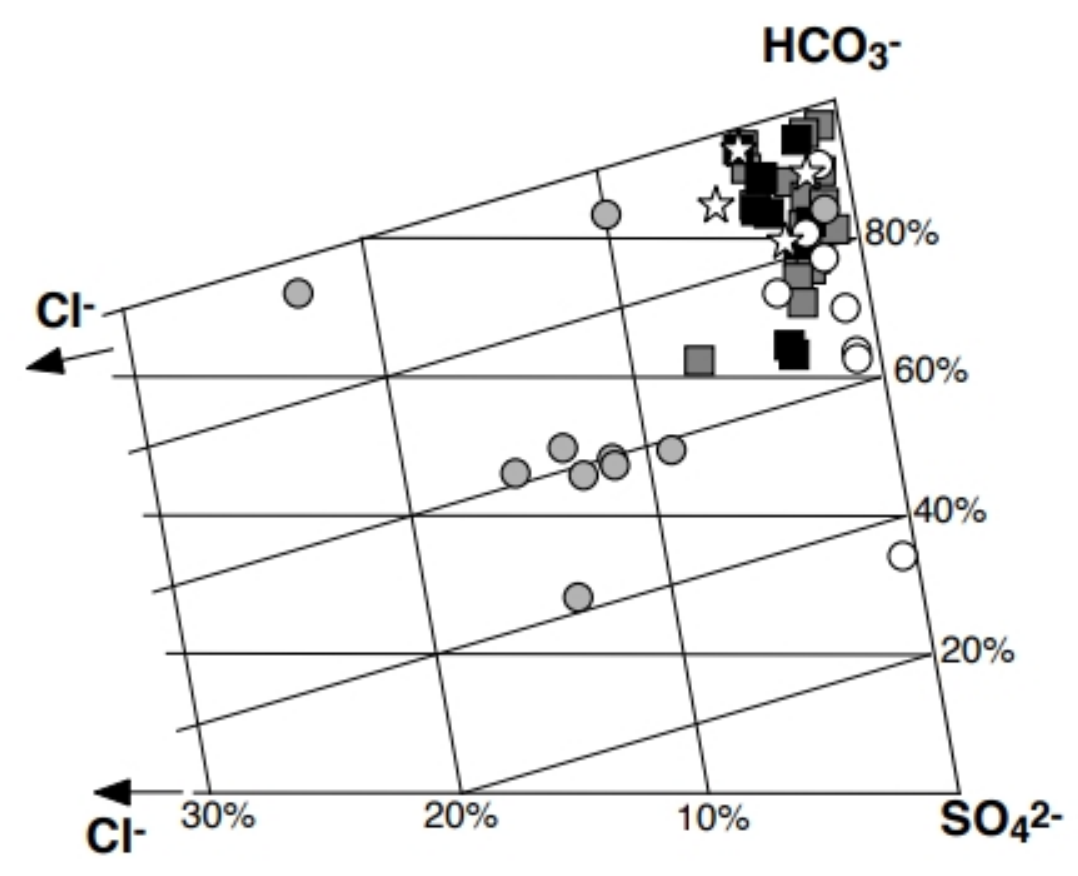



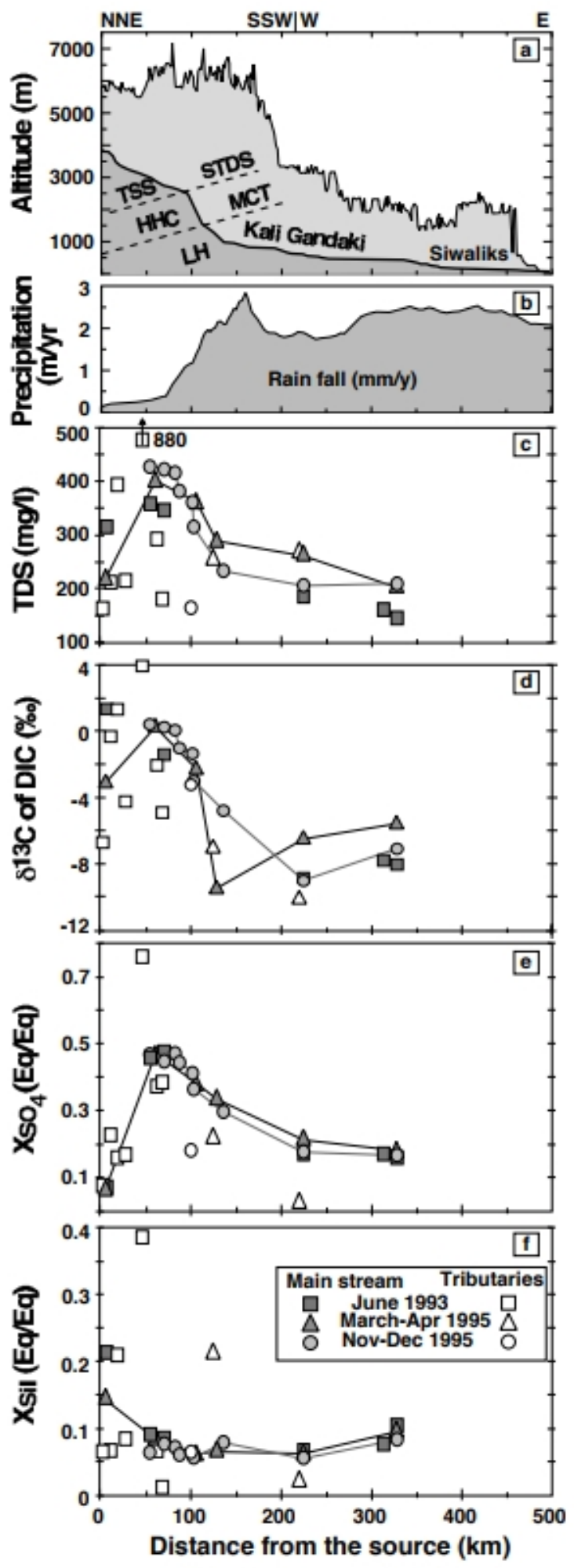
Fig. 5

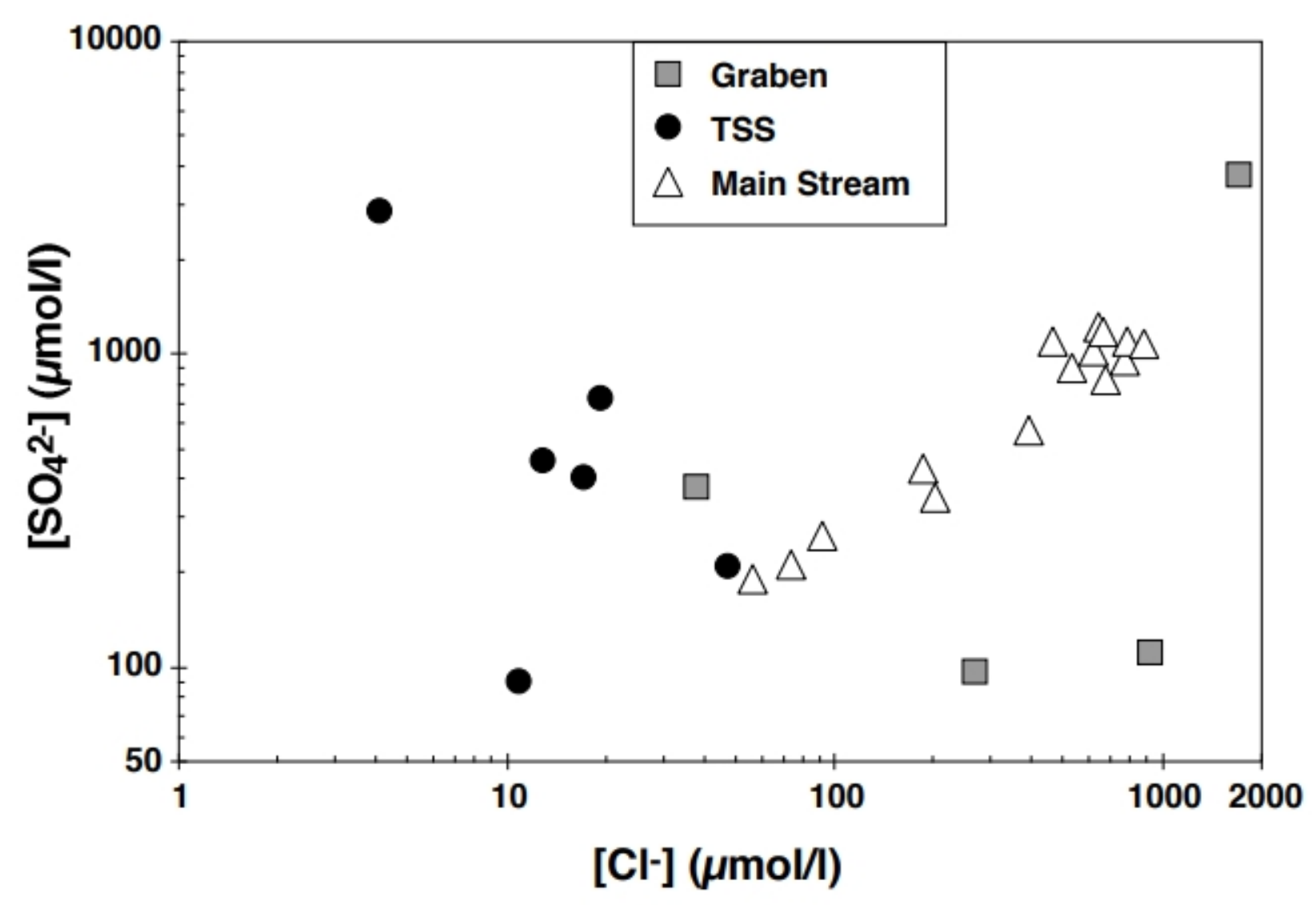


Fig. 6

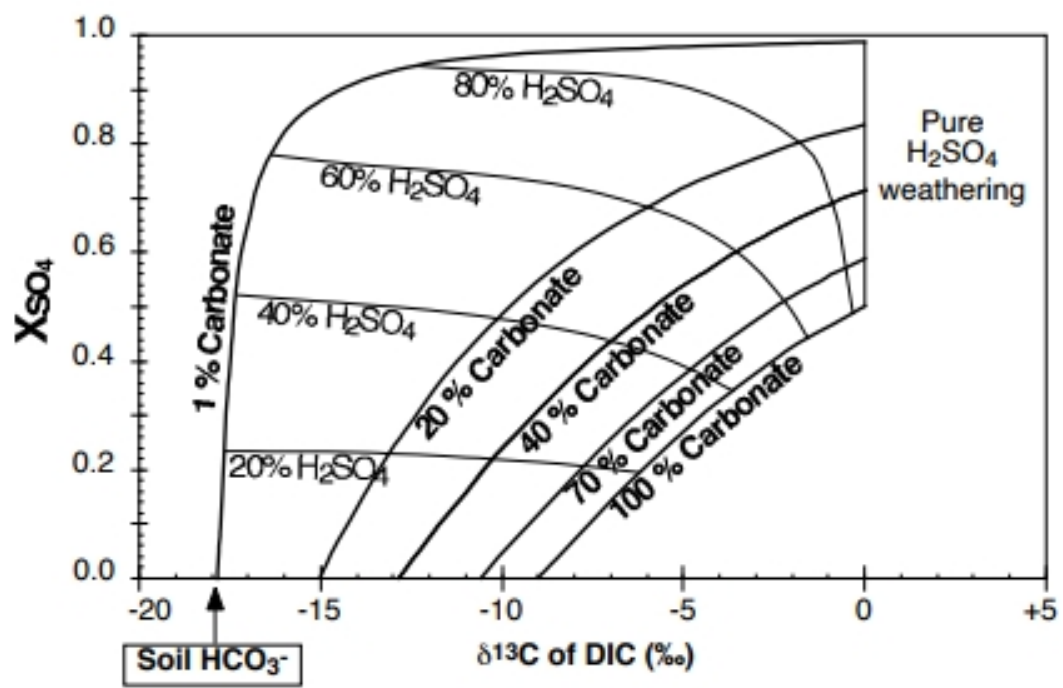

Fig. 6a

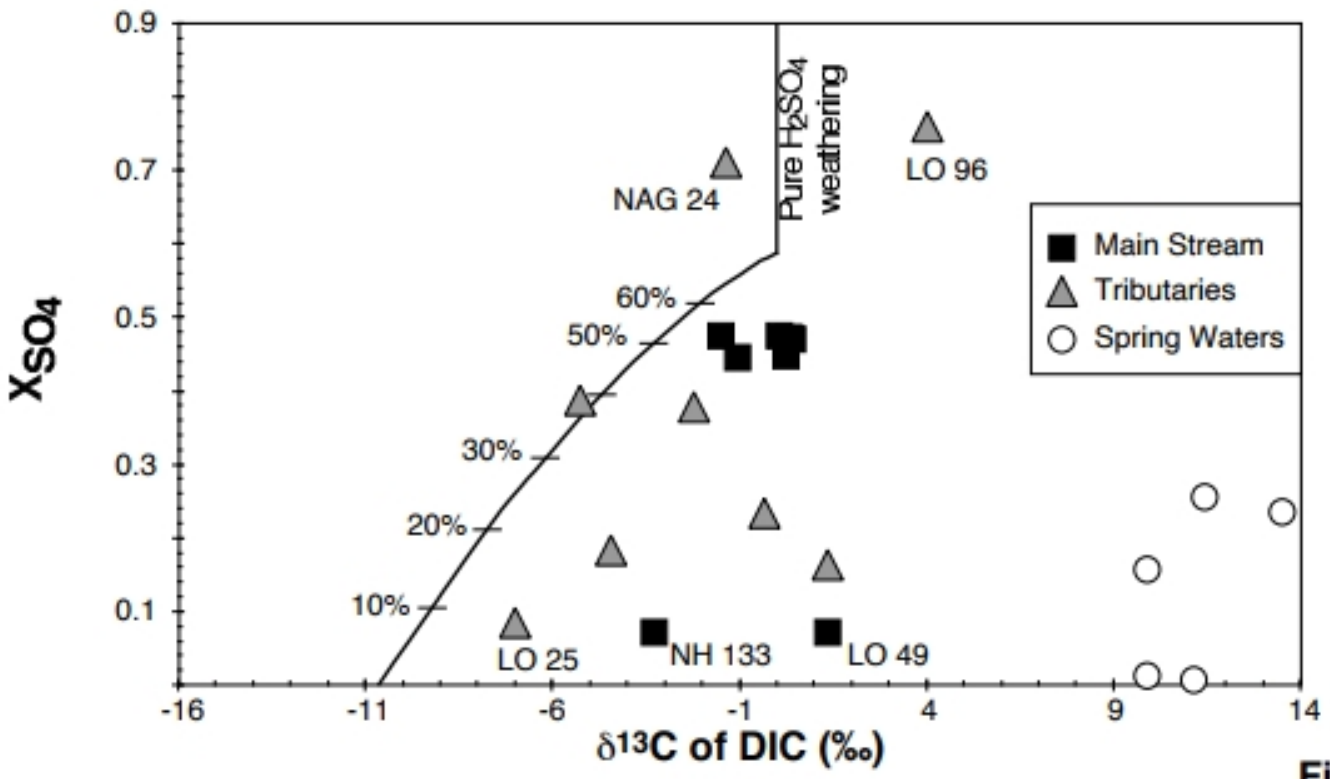

Fig. 6b

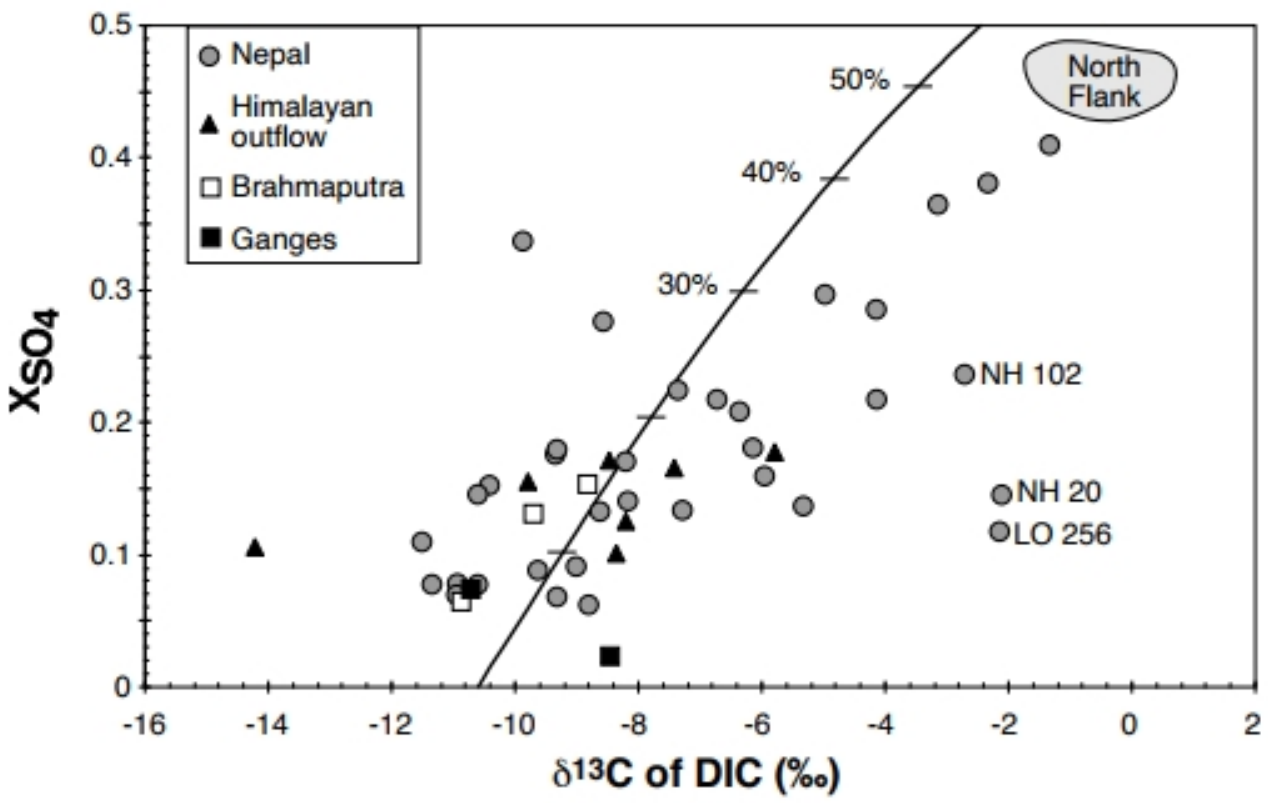


Fig. 7
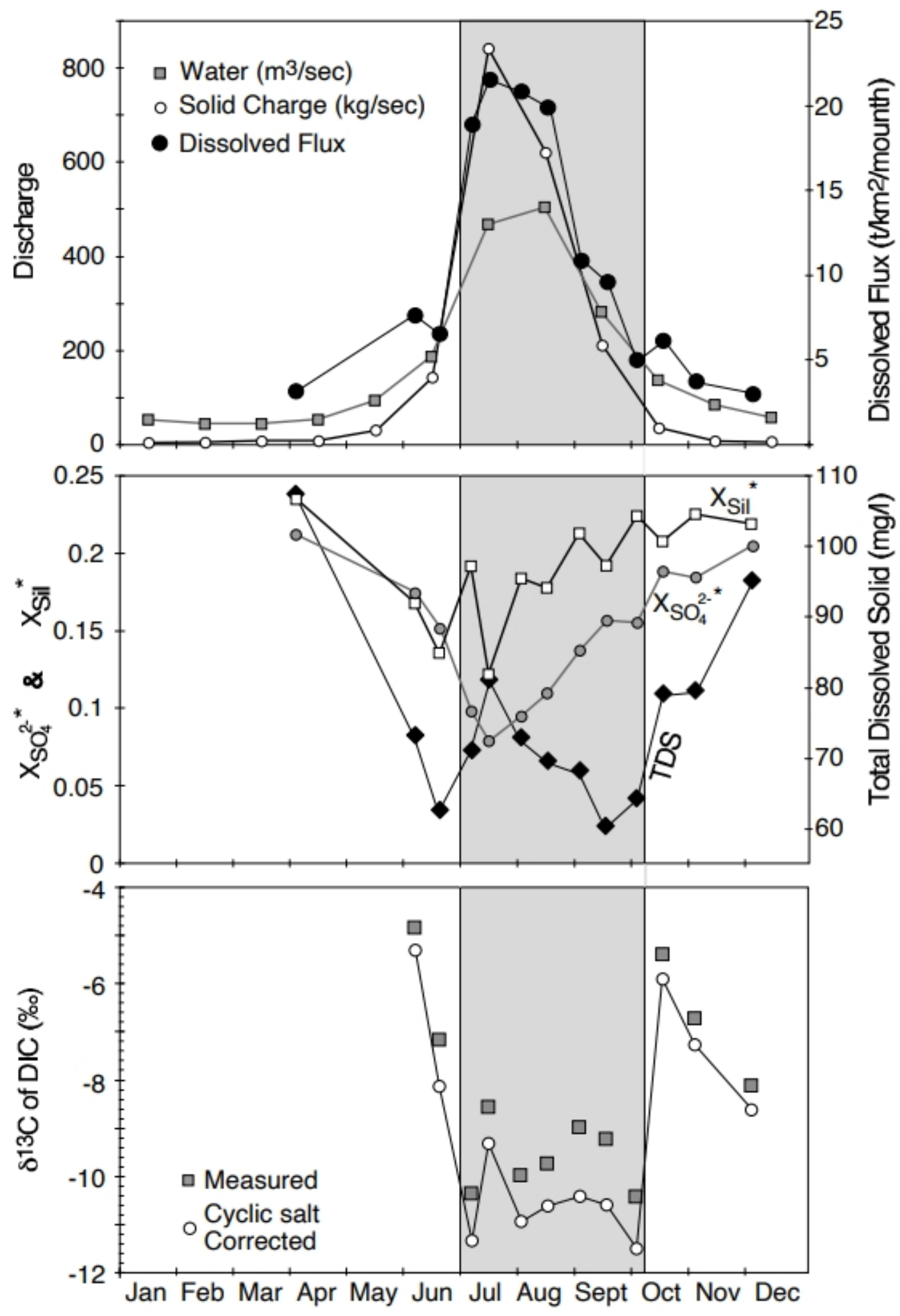
Fig. 8

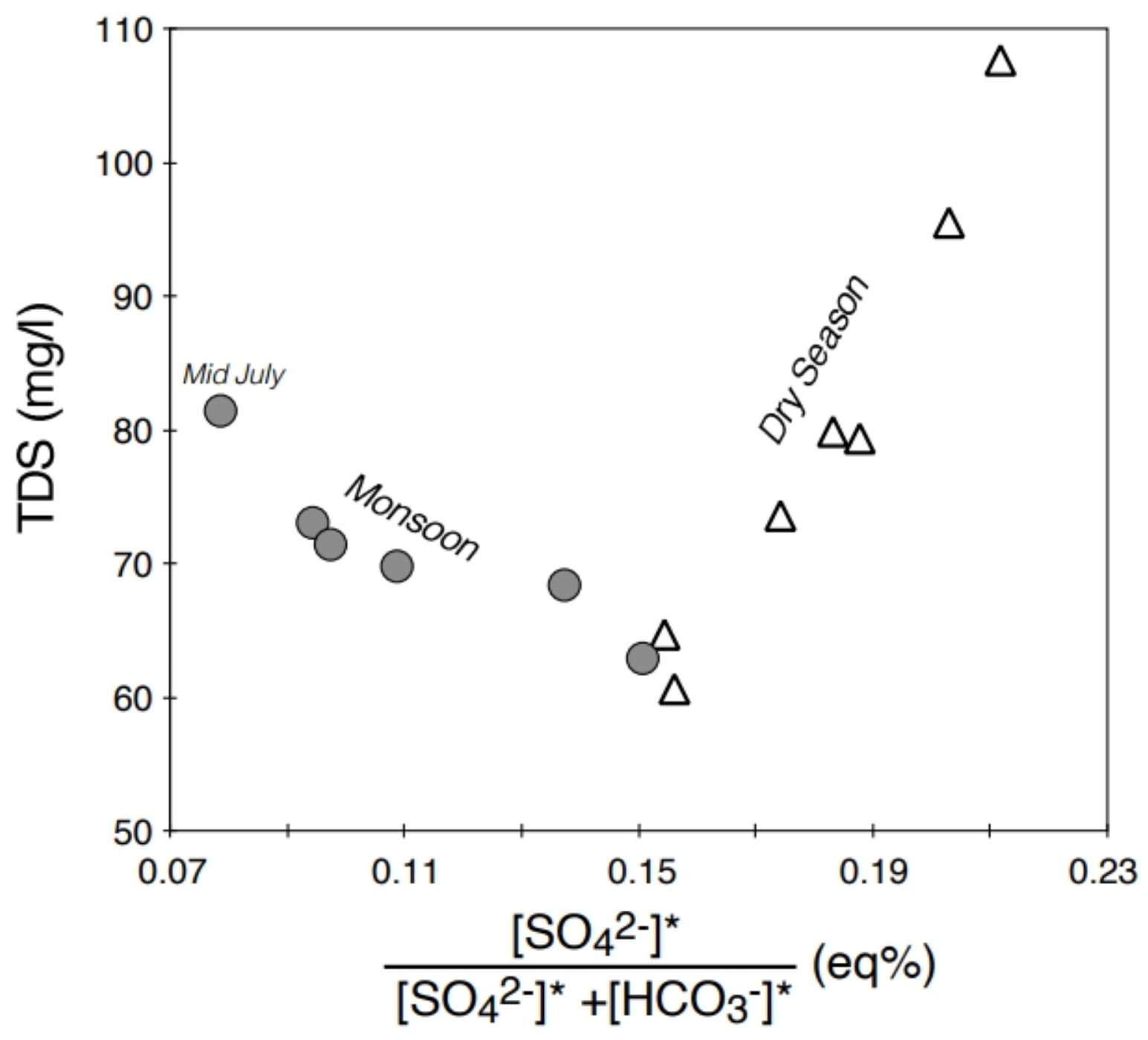


Fig. 9

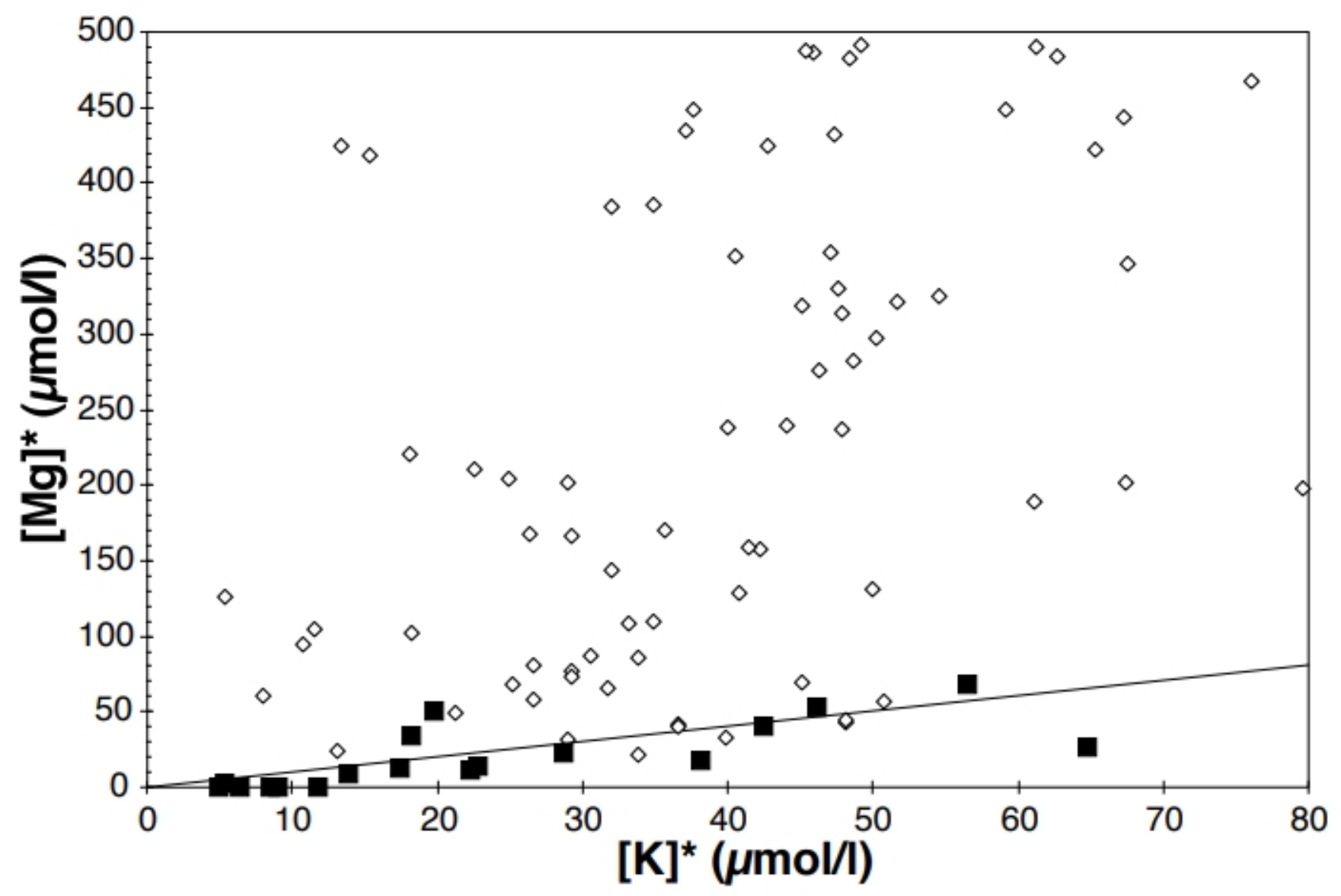

